FACULDADES UNIFICADAS DE FOZ DO IGUAÇU - UNIFOZ CURSO DE DIREITO

MARCIA APARECIDA ZANOTTI

FEMINICÍDIO E VIOLÊNCIA DE GÊNERO

FOZ DO IGUAÇU/PR 
MARCIA APARECIDA ZANOTTI

\section{FEMINICÍDIO E VIOLÊNCIA DE GÊNERO}

Monografia apresentada como requisito parcial para obtenção do grau de Bacharel em Direito das Faculdades Unificadas de Foz do Iguaçu UNIFOZ.

Orientador Prof.: Marcelo Gobbo Dalla Déa

FOZ DO IGUAÇU/PR 


\section{FEMINICÍDIO E VIOLÊNCIA DE GÊNERO}

Monografia aprovada, apresentada a Faculdades Unificadas de Foz do Iguaçu - UNIFOZ, Curso de Direito, como requisito parcial para a obtenção do título de Bacharel em Direito, com nota final igual a _ conferida pela Banca Examinadora formada pelos professores:

Orientador Prof.: Marcelo Gobbo Dalla Déa

Faculdades Unificadas de Foz do Iguaçu - UNIFOZ

Prof.

Faculdades Unificadas de Foz do Iguaçu - UNIFOZ

Foz do Iguaçu/PR. de de 2019. 
Dedico este trabalho in memoriam a minha mãe Neusa Maria Salim. 


\section{AGRADECIMENTOS}

Aos meus filhos pelo amor incondicional, por todo apoio. $E$ que, mais que ninguém aguentaram meus momentos de estresse a cada semana de prova, entrega e apresentação de trabalhos, e pela compreensão da importância dessa realização em minha vida.

Aos amigos, por entenderem a minha ausência e por me ouvirem sempre que me empolgava e falava sempre sobre o tema do meu TCC, e por me enviarem artigos e notícias sempre que viam algo relacionado ao tema escolhido.

Aos meus colegas e amigos do curso pela troca de informações, apoio e incentivo uns aos outros, foi muito relevante para que eu chegasse até aqui.

Aos professores do curso de Direito e a coordenadora do curso, Professora Camila, por não medirem esforços para que tivéssemos a melhor das experiências acadêmicas e que a cada noite nos incentivava a seguir nossos sonhos nos proporcionando o conhecimento necessário para tal.

Ao professor orientador Marcelo Gobbo, e professora de monografia Jéssica Aparecida Soares, que me incentivou e apoiou em todos os momentos dessa jornada, e me ensinou, mais que os requisitos básicos para realização deste trabalho, mas a olhar com humanidade para os problemas sociojurídicos e sociais existentes no universo feminino em nossa sociedade brasileira.

À Deus que, com fé e esperança, me sustentou até aqui e não permitiu que eu desistisse diante as dificuldades enfrentadas nessa jornada.

Dedico-vos toda a minha gratidão. Muito obrigada. 
ZANOTTI, Márcia Aparecida. Feminicídio e Violência de Gênero. 61f. Monografia para conclusão de Graduação em Direito - Faculdades Unificadas de Foz do Iguaçu - UNIFOZ, Foz do Iguaçu, 2019.

\section{RESUMO}

O projeto visa fazer uma arguição sociojurídica e sociocultural da apresentação do entendimento da violência de gênero no ordenamento jurídico brasileiro e na sociedade. Através da apresentação das Leis 13.104/2015 e 11.340/2006, com destaque na segunda que aborda sobre o feminicídio, fundamentando-se aplicação da legislação penal que avança a punição de homens, companheiros (as) que matam em razão do gênero. Também foram apresentados a relação da desigualdade de gênero com a ocorrência da violência contra a mulher e sua resistência no passar dos anos dos séculos da história da humanidade. Diante dos dados apresentados e da pesquisa realizada, foi possível concluir que a violência de gênero permanece presente na realidade brasileira, vitimando muitas mulheres, fazendo-se necessária adequação da legislação no sentido de punir, prevenir e erradicar esta forma de violência, a mobilização de uma política pública e investimentos de recursos para que os mecanismos de prevenção a morte das mulheres efetivamente coibida e erradicada de nossa sociedade.

PALAVRAS-CHAVES: Violência Doméstica. Violência de Gênero. Mulher. Feminicídio. 
ZANOTTI, Márcia Aparecida. Femicide and Gender Violence. 61f. Monograph for a Law Graduation conclusion - Faculdades Unificadas de Foz do Iguaçu - UNIFOZ, Foz do Iguaçu, 2019.

\section{ABSTRACT}

The project aims to make a socio-legal and socio-cultural argument of the presentation of the understanding of gender violence in the Brazilian legal system and in society. Through the presentation of Laws 13.104 / 2015 and 11.340 / 2006, highlighting the second that deals with femicide, based on the application of criminal law that advances the punishment of men, partners who kill on the grounds of gender. Also presented were the relationship of gender inequality with the occurrence of violence against women and its resistance over the centuries of human history. Given the data presented and the research conducted, it was possible to conclude that gender violence remains present in the Brazilian reality, victimizing many women, making it necessary to adapt the legislation to punish, prevent and eradicate this form of violence, the mobilization of women. a public policy and resource investment so that the mechanisms for preventing the death of women effectively curbed and eradicated from our society.

KEYWORDS: Domestic violence. Gender violence. Woman. Femicide. 


\section{SUMÁRIO}

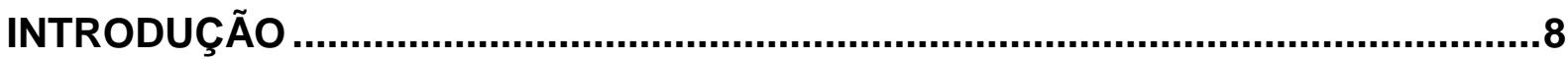

1 DA CULTURA PATRIARCAL MACHISTA A VIOLÊNCIA CONTRA MULHER 10

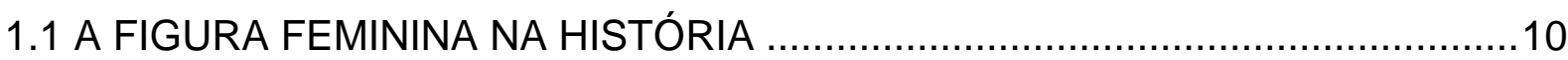

1.2 VIOLÊNCIA DE GÊNERO

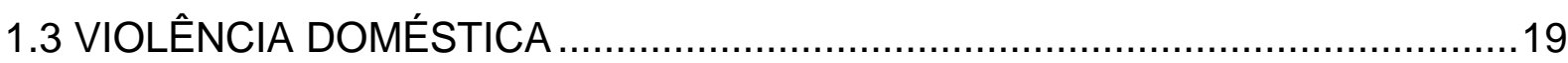

2 A VIOLÊNCIA CONTRA MULHER

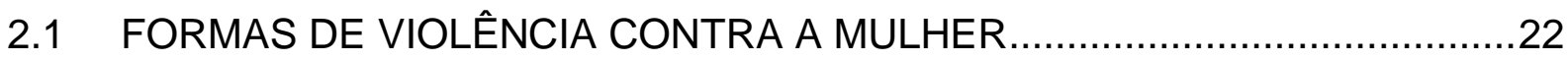

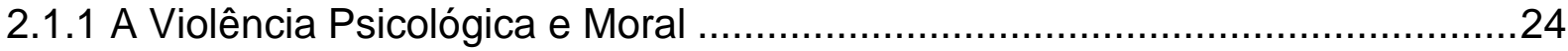

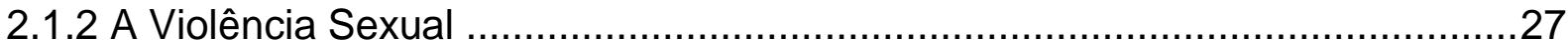

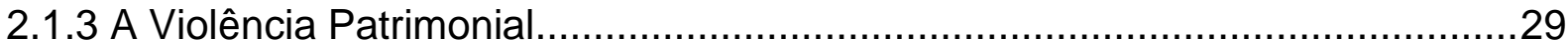

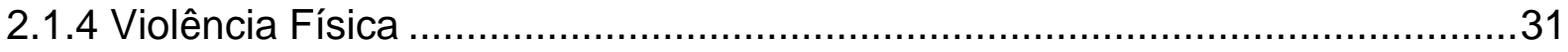

3 FEMINICÍDIO: A RELAÇÃO ENTRE VIOLÊNCIA DE GÊNERO E VIOLÊNCIA

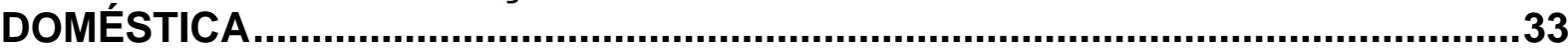

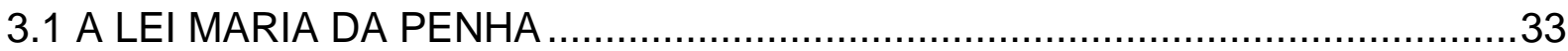

3.1.1 Ampliam-se as Leis de Proteção das Mulheres Vítimas de Violência ...............37

3.1.2 Legislação Contra a Violência da Mulher no Brasil .........................................38

3.1.3 Precedentes Originários da Súmula 588 do STJ....................................... 42

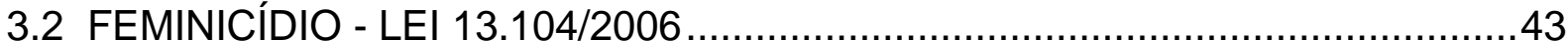

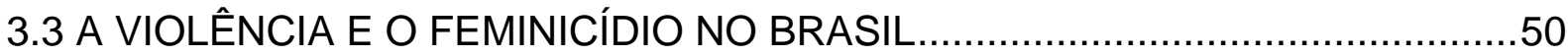

3.3.1 Pena Maior para Crime de Feminicídio foi Aprovada em 2018 …...................53

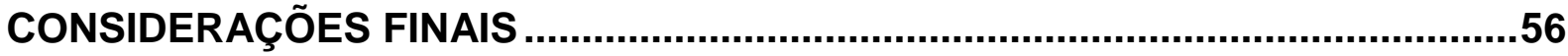

REFERENCIAL BIBLIOGRÁFICO 


\section{INTRODUÇÃO}

A violência contra mulher é situação perpetrada desde os tempos mais remotos da história humana, a figura feminina é desde sua origem relativizada como um ser inferior, como coisa, objeto, tanto no âmbito familiar, social e jurídico, devendo sempre obedecer ao homem como ser superior.

A mulher no decorrer de décadas, conquistou seu espaço, no trabalho, nos estudos, profissionalmente, teve um avanço significativo no Código Civil Brasileiro e Código Penal Brasileiro. Evoluíram, também, reconhecendo a mulher como um indivíduo, com seus direitos previsto na Constituição Brasileira de 1988, no artigo $5^{\circ}$ que versa sobre o direito de igualdade entre homens e mulheres, brasileiros e estrangeiros.

$\mathrm{Na}$ verdade, mesmo diante de todas as lutas por igualdade e proteção as mulheres continuam sendo vítimas de agressões, levando inclusive a perderem suas vidas. É nesse contexto que está inserido o tema proposto para este trabalho.

A violência de gênero contra as mulheres é uma questão sociocultural, e patriarcal que é passado de geração em geração, englobando todos os preconceitos e desigualdades.

O objetivo deste trabalho é analisar a relação e a influência da violência de gênero e a violência domésticas, que é o caminho sem volta ao crime hediondo, o feminicídio, tendo como relevância acadêmica contribuir para a compreensão de que um dos maiores obstáculos para a efetividade dos dispositivos legais existentes sobre a violência contra mulher e qual a responsabilidade da sociedade, do Estado e dos mecanismos de segurança brasileiro.

As raízes do sistema patriarcal e de concepções machistas ainda criam obstáculos para que a mulher, biologicamente ou juridicamente identificada, continue a ser vítima de agressões físicas, psicológicas, patrimoniais, sexuais, culminando com sua morte.

Há muitos crimes contra as mulheres que são qualificados por homicídio, por falta de estrutura de reconhecimento da violência de gênero. Muitos destes 
assassinos criminosos e geralmente com relação afetiva atual ou pós relacionamento, matam pelo fato da vítima ser mulher, com crueldade específicas de violência de gênero, mutilando seu corpo, desfigurando seu rosto, seus seios e genitálias.

Busca-se evidenciar a necessidade que a situação seja devidamente identificada como violência de gênero, para que o crime de feminicídio possa ser reconhecido e devidamente punido.

Atualmente, tem-se aumentado a preocupação com o fenômeno da morte de mulheres vítimas da violência de gênero, aperfeiçoando a sua especialização por via da legislação, que consiste na criminalização da violência contra as mulheres, não só pelas normas ou leis, mas, também, através da consolidação de aparelhos mobilizadores que protejam as vítimas e punam seus agressores.

A Lei n. 11.340, de 07 de agosto de 2006, conhecida como Lei Maria da Penha, representa um marco na proteção aos direitos das mulheres, pois tem como premissa coibir e prevenir todas as formas de violência doméstica e familiar. Do mesmo modo, em março de 2015, no Brasil, o feminícidio foi tipificado como conduta criminosa, através da Lei n. 13.104, de 09 de março de 2015.

Deste modo, o trabalho apresentado será dividido em três capítulos. O primeiro capítulo aborda a figura feminina na história, possibilitando compreensão acerca das raízes socioculturais que permitem a propagação da violência contra mulher, identificando ainda a violência de gênero como classe abrangente dentro da qual estão inseridas as formas de violência contra mulher.

O segundo capítulo traz analise especifica sobre as formas de violência contra mulher, verificando sua previsão conforme a Lei Maria da Penha e Código Penal Brasileiro.

O terceiro capítulo versa sobre a Lei n. 13.104/2015, que foi tipificada no Brasil no mês de março de 2015 como conduta criminosa, através do feminicídio.

Por fim, analisando os dispositivos legais que visam coibir, prevenir e punir a violência contra mulher se pode compreender a instituição da qualificadora do feminicídio, dentro da qual são vítimas mulheres biológica e juridicamente identificadas, prezando pelos Direitos Fundamentais de Igualdade de raça, de cor, de sexo, e assim por diante. 


\section{DA CULTURA PATRIARCAL MACHISTA A VIOLÊNCIA CONTRA MULHER}

\subsection{A FIGURA FEMININA NA HISTÓRIA}

Analisando a história e a evolução da sociedade humana pode-se constatar que a mulher, quase que em geral, sempre foi vista como objeto de satisfação e posse. Pertencia inicialmente a seu pai e posteriormente pertenceria a seu marido, devendo agir sempre dentro dos limites morais e do que era "aceitável" para o padrão de comportamento de uma mulher.

Tales dos Santos Pinto comenta neste sentido:

As explicações podem estar relacionadas ao fato de que a preponderância e dominação masculina foram instituídas, ao menos nas sociedades ocidentais, desde os primórdios da civilização grega. Esta situação levou a uma dupla situação: eram os homens que conduziam predominantemente as ações políticas e militares; ao mesmo tempo em que eram os historiadores do sexo masculino que escreviam a história destas ações. A consequência foi uma subalternidade das mulheres nos domínios políticos e militares públicos (já que no âmbito doméstico a situação era um pouco distinta) e também como objeto de estudo historiográfico. ${ }^{1}$

Em tempos não muito antigos, a situação da mulher era de tamanho desprezo que, ao se casar, se o marido "constatasse" que ela não era virgem - mesmo que o fosse dada as características biológicas de cada ser humano - ela seria devolvida a sua família em situação de vergonha, o mesmo ocorria com aquelas que não conseguiam gerar filhos.

Situação narrada por Fustel de Coulanges em seu livro "A cidade antiga":

Como o casamento não era contratado senão para perpetuar a família, parece justo que podia ser anulado se a mulher fosse estéril. Nesses casos, o divórcio sempre constituiu direito entre os antigos; é

\footnotetext{
${ }^{1}$ PINTO, Tales dos Santos. As mulheres na história. [S.n.t.]. Informação postada no site Mundo Educação. Disponível em: <https://mundoeducacao.bol.uol.com.br/historiageral/as-mulheres-na-historia.htm〉. Acesso em: 25 set. 2019.
} 
até possível que tenha sido uma obrigação. $\mathrm{Na}$ Índia, a religião prescrevia que "a mulher estéril fosse substituída depois de oito anos." - Nenhum texto formal prova que esse dever fosse idêntico tanto na Grécia quanto em Roma. Contudo, Heródoto cita dois reis de Esparta que foram constrangidos a repudiar as mulheres, porque eram estéreis. Quanto a Roma, é bastante conhecida a história de Carvílio Ruga, cujo divórcio é o primeiro mencionado pelos Anais de Roma. "Carvílio Ruga - diz Aulo Gélio - homem de grande família, separou-se da mulher mediante divórcio, porque não podia ter filhos dela. Amava-a ternamente, e só podia louvar-Ihe a conduta. Mas sacrificou seu amor à religião do juramento, porque havia jurado na fórmula do casamento - que a tomava por esposa a fim de ter filhos."

No caso em que uma mulher ficasse viúva sem ter filhos com seu marido, cabia ao irmão solteiro desse ou ao parente mais próximo na sua falta, casar-se com ela e assumir o comando da família bem como de dar prosseguimento a descendência de seu irmão, situação conhecida como casamento levirato. ${ }^{3}$

A mesma situação é evidenciada nas palavras de Fustel de Coulanges quando a esterilidade ocorria por parte do marido, seu irmão ou parente próximo deveria assumir seu lugar na procriação, para que sua família tivesse prosseguimento:

\begin{abstract}
A religião dizia que a família não podia extinguir-se; toda afeição e direito natural devia ceder diante dessa regra absoluta. Se o casamento era estéril por causa do marido, nem assim a família podia deixar de continuar. Nesse caso, um irmão ou parente do marido devia substituí-lo, e a mulher era impedida de se divorciar. A criança nascida dessa união era considerada filha do marido, e continuava seu culto. Tais eram as regras entre os antigos hindus; tornamos a encontrá-las nas leis de Atenas e de Esparta. Tal era a força imperiosa da religião! Tal a importância do dever religioso, que passava à frente de todos os outros! ${ }^{4}$
\end{abstract}

Nesses casos o que se pode constatar é que a mulher não poderia possuir desejos ou vontades, cabia a ela apenas aceitar o destino que the era imposto por sua família, jamais poderia fazer objeção a qualquer conduta que the fosse requerida.

\footnotetext{
${ }^{2}$ COULANGES, Fustel de. A Cidade Antiga. Tradução de Frederico Ozanam Pessoa de Barros. São Paulo: Edameris, 1961. p.37.

${ }^{3}$ CONEGERO, Daniel. O Que Significa a Lei do Levirato? [S.n.t.]. Informação postada no site Estilo adoração. Disponível em: 〈https://estiloadoracao.com/lei-do-levirato/>. Acesso em: 25 set. 2019.

${ }^{4}$ COULANGES, Fustel de. Op. cit., p. 38.
} 
Arnaldo Rizzardo demonstra como as raízes patriarcais estão vinculadas a existência da família e consequentemente da sociedade, de forma que em regra sempre foi regida pelos homens, às mulheres restavam somente os afazeres domésticos:

\begin{abstract}
No início, sob a direção pater família, uma vez organizadas as sociedades primitivas, a família reunia todos os descendentes de um tronco comum (família patriarcal), unificada em função do culto religioso e de fins políticos e econômicos. Fundado na união solene entre cônjuges, esse modelo influenciou entre séculos a vida em sociedade, plasmando-se juridicamente nas codificações, em razão da multiplicidade dos costumes e da perfeita divisão de funções entre homem e mulher. Mas sempre se viu na família a célula-mater da organização social. Aos poucos foi-se imprimindo alcance mais restrito para o núcleo, considerando como tal apenas os familiares sob a égide dos pais, mas ainda com o marido na chefia do lar conjugal e na administração dos bens da família, enquanto à mulher competia os afazeres domésticos. ${ }^{5}$
\end{abstract}

O homem na antiguidade sempre esperava que ao se casar tivesse o primeiro filho do sexo masculino e desse gênero, quantos filhos fossem possíveis, pois 0 crédito maior era que o filho daria continuidade a seu nome, a religião e ao núcleo familiar, se um pai de família gerasse somente filhas mulheres acreditava-se que poderia estar amaldiçoado, uma vez que essas não "serviam" para nada a não ser para serem boas esposas e cuidar dos afazeres domésticos.

A filha não poderia dar continuidade a família do pai, se nascesse uma filha mulher o objetivo do casamento ainda não estava consumado, já que essa ao se casar passaria a pertencer a família de seu marido. ${ }^{6}$

Michelle Perrot narra a invisibilidade a que a mulher foi submetida na história:

Escrever a história das mulheres atuam em família, confinadas em casa, ou no que serve de casa. São invisíveis. Em muitas sociedades, a invisibilidade e o silêncio das mulheres fazem parte da ordem das coisas. É a garantia de uma cidade tranquila. Sua aparição em grupo causa medo. Entre os gregos, é a stasis, a desordem. Sua fala em público é indecente. "Que a mulher conserve o silêncio, diz o apóstolo Paulo. Porque primeiro foi formado Adão, depois Eva. E não foi Adão que foi seduzido, mas a mulher que,

\footnotetext{
${ }^{5}$ RIZZARDO, Arnaldo. Direitos de Família. 10. ed. Rio de Janeiro: Forense, 2019. p. 48.

${ }^{6}$ COULANGES, Fustel de. A Cidade Antiga. Tradução de Frederico Ozanam Pessoa de Barros. São Paulo: Edameris, 1961, p. 38
} 
seduzida, caiu em transgressão." Elas devem pagar por sua falta num silêncio eterno. Até mesmo o corpo das mulheres amedronta. $\mathrm{E}$ preferível que esteja coberto de véus. Os homens são indivíduos, pessoas, trazem sobrenomes que são transmitidos. Alguns são "grandes", "grandes homens". As mulheres não têm sobrenome, têm apenas um nome. Aparecem sem nitidez, na penumbra dos grupos obscuros. "As mulheres e as crianças", "primeiro", ou ao lado, ou para fora, dependendo do caso: a expressão clássica traduz essa globalização. No começo de Tristes tropiques, Claude Lévi-Strauss descreve uma aldeia depois da partida dos homens para caçar: não havia mais ninguém, diz ele, exceto as mulheres e as crianças ${ }^{7}$

O que se pode entender é que a figura feminina na realidade aparentava ser temida, talvez por seu poder de influenciar decisões, talvez por exemplo de mulheres notáveis que a história fez questão de registrar, como Catarina de Médici, entre tantas outras, que comprovou que poderia uma mulher governar o destino de uma nação sem perder-se em sua feminilidade. ${ }^{8}$

Em que pese as guerras, o capitalismo os movimentos revolucionários por ele influenciado terem contribuído para uma forma de desintegrar costumes e ideias patriarcais, o mesmo não se pode constatar com referência ao machismo, o qual se incumbiu da função de manter a mulher como figura de tratamento desigual, em posições subalternas, como se não fosse merecedora de direitos e proteção.

Desse período do Capitalismo e ao inserimento das mulheres no trabalho e dos menores, sendo visto como mão de obra barata eficaz, ocorria muitas mortes por não terem condições de trabalho adequado, trabalhando mais de doze horas por dia e ainda enfrentando dupla jornada de trabalho com os afazeres domésticos, e dos filhos e esposo, trabalhando sem proteção alguma em lugares insalubres.

Provieram movimentos de lutas pelos direitos femininos, onde se pode ter acesso a salário, estabilidade no trabalho, direito a carteira registrada com as devidas garantias, licença maternidade. As feministas tiveram grande importância na evolução das mulheres e seus direitos. Assim sendo o Estado verificando grande número de acidentes de trabalho e mortes das mulheres, teve que tomar medidas na legislação de direitos e proteção trabalhista as mulheres, nisso os menores também se beneficiaram, tornando proibido o trabalho de menores, fatores importantes nos

\footnotetext{
${ }^{7}$ PERROT, Michelle. Minha história das mulheres. Tradução de Angela M. S. Côrrea. São Paulo: Contexto, 2007. p. 17.

${ }^{8}$ Ibid., p. 18.
} 
direitos femininos, mas que ainda não alcançaram o êxito total como de salários iguais aos dos sexo masculino, mesmo exercendo as mesmas funções igual ou melhor que aos homens.

É notória a história de luta por igualde e direitos da mulher e nesse, a importância dos movimentos feministas, através dos quais muitos dos direitos hoje positivados foram obtidos.

A mulher por muito tempo foi totalmente desprezada, relativizada em desigualdade com relação ao homem, sua posição na sociedade, ainda hoje cultivada, é a de que nasceu para ser esposa e mãe, jamais para ser independente e ser dona de sua própria vida.

Segundo Maria Berenice Dias, a mulher ficou restrita ao espaço do lar, com a obrigação de cuidar do marido e dos filhos, enquanto ao homem coube o espaço público, o que colaborou para a formação de dois mundos, uma separação que culminou ao homem o espaço da dominação, externo, produtor, já ao outro, coube o espaço da submissão, interno e reprodutor. O provedor da família e a protetora do lar, cada um desempenhando sua função. ${ }^{9}$

Pierre Bourdieu ${ }^{10}$ destaca que as mulheres, uma vez excluídas da esfera pública, ou seja do "universo das coisas sérias", elas "ficaram durante muito tempo confinadas ao universo doméstico e às atividades associadas à reprodução biológica e social da descendência", adiciona-se a isso o fato de que o trabalho doméstico das mulheres, ainda nos dias atuais, não faz jus a remuneração alguma, contribui para desvalorizá-la e perpetuar a dominação patriarcal.

Os diferentes padrões de comportamento, analisado por Maria Fernanda Siares Fonseca et al, estabelecidos para homens e mulheres geram a construção de um código de conduta. Ao macho é atribuído um papel paternalista, colocando a fêmea em uma situação de submissão. ${ }^{11}$

\footnotetext{
${ }^{9}$ DIAS, Maria Berenice. Manual de Direito das Famílias. $7^{\mathrm{a}}$ ed. São Paulo: Ed. RT, 2010.

${ }^{10}$ BOURDIEU, Pierre. A Dominação Masculina. Tradução de Maria Helena Kühner. Rio de Janeiro: Bertrand Brasil, 1999. p. 116.

11 FONSECA, Maria Fernanda Soares et al. O Feminicídio como uma Manifestação das Relações de Poder entre os Gêneros. v. 28, n. 1, p. 49-65, Rio Grande: Juris, 2018.
} 
Partindo disso, Maria Berenice Dias diz que há uma diferença na educação das mulheres, moldadas para serem controladas e terem seus desejos reprimidos. Por isso, a restrição ao exercício da sexualidade e a consagração da maternidade. Ambos os universos, distantes, mas dependentes entre si, buscam manter suas contradições estabelecidas, mantendo o modelo de submissão alicerçado no autoritarismo. ${ }^{12}$

Carolina Cunha explica que a história dos movimentos feministas remonta às antigas leis que colocavam a mulher como coisa, limitada, sem nenhuma previsão de proteção e direitos, sendo que a partir do século XVIII é que começaram os primeiros movimentos que reivindicavam direitos das mulheres. ${ }^{13}$

Os movimentos feministas passaram a surgir com mais intensidade com a ocorrência da Revolução Francesa, período de grande influência no requerimento de direitos em vários setores.

Tié Lenzi narra esse período histórico:

A partir das mudanças trazidas pela Revolução Francesa as mulheres começaram a tomar consciência das desigualdades a que eram submetidas e, pouco a pouco, passaram a questionar os modelos sociais e lutar para diminuir a desigualdade política e de direitos. Esse período ficou conhecido como a primeira onda do feminismo. Neste mesmo período surgiu o movimento sufragista, formado principalmente por mulheres inglesas para garantir o direito da participação feminina nas eleições. Emmeline Pankhurst foi um dos grandes nomes do movimento sufragista, assim como a escritora Mary Wollstonecraft, que também defendeu em seus livros o direito de voto das mulheres. ${ }^{14}$

O episódio ocorrido em Nova York em 8 de março de 1857 onde 129 operárias morreram carbonizadas por conta de represália policial contra a greve que faziam por seus direitos, requeriam que sua jornada de trabalho fosse reduzida para 10 horas diárias e não mais as 12 que faziam, é um dos mais famosos da história do

\footnotetext{
12 DIAS, Maria Berenice. Manual de Direito das Famílias. $7^{\text {a }}$ ed. São Paulo: Ed. RT, 2010.

${ }^{13}$ CUNHA, Carolina. Direitos femininos: uma luta por igualdade e direitos civis. [S.n.t.]. Informação postada no site UOL. Disponível em: <http://vestibular.uol.com.br/resumo-das-disciplinas/atualidades/direitos-femininosuma-luta-por-igualdade-e-direitos-civis.htm>. Acesso em: 15 out. 2019.

${ }^{14}$ LENZI, Tié. O que é o movimento feminista?. [S.n.t.]. Informação postada no site Toda política. Disponível em: <https://www.todapolitica.com/movimento-feminista/>. Acesso em: 15 set. 2019.
} 
feminismo, servindo inclusive de motivo para instituição do Dia Internacional da Mulher, atualmente comemorado. ${ }^{15}$

Os movimentos pró direitos femininos colocaram em pauta publicamente a situação que a sociedade tentava abafar: as mulheres já não eram mais apenas a 'rainha do lar", estava cada vez mais inserida no mercado de trabalho e em funções vitais na sociedade.

Nesse contexto de lutas por igualdade e liberdade, surgiu ainda outro fator que contribuiu para o avanço no controle das mulheres sobre o próprio corpo: a pílula anticoncepcional, possibilitando que as mulheres pudessem ao menos em parte, decidir sobre sua natalidade. Destaca-se também que esse período foi de avanços para o setor intelectual, destacando mulheres na posição de autores de obras até hoje comentadas, tais como Simone de Beauvior, autora de "O segundo sexo".

Sobre os movimentos de lutas por direitos e igualdade da mulher Tales Santos comenta:

As lutas pelo direito ao voto, de salário e direitos trabalhistas iguais foram se desenvolvendo durante o século XX, encontrando o auge com o movimento feminista na década de 1960. A partir de lutas cotidianas, às vezes silenciosas, a situação foi aos poucos mudando, sendo que ainda na segunda década do século XXI muitas diferenças entre homens e mulheres no âmbito das relações sociais ainda permanecem. Entretanto, várias conquistas foram alcançadas, principalmente no que diz respeito às relações trabalhistas, políticas, empresariais e de liberdade sexual. Na esfera doméstica, as mudanças ocorrem num ritmo mais lento. A violência doméstica ainda é uma realidade constante na vida cotidiana de milhões de mulheres. Mas, por exemplo, no Brasil, tal realidade vem sendo combatida com a Lei Maria da Penha, promulgada em 2006. ${ }^{16}$

A desigualdade existente entre homens e mulheres ainda nos dias atuais é latente, costume ainda perpetrado, por uma sociedade de raízes machistas que não

\footnotetext{
${ }^{15}$ MALTA, Cynthia Guimarães Tostes. Evolução dos direitos da Mulher. [s.n.: S.1.], 25 fev. 2002. Informação postada no site Geocites. Disponível em: <http://www.geocities.ws/cynthiamalta/dirmul.html>. Acesso em: 15 out. 2019.

${ }^{16}$ SANTOS, Tales. As mulheres na história. [S.n.t.]. Informação postada no site Mundo Educação. Disponível em: <https://mundoeducacao.bol.uol.com.br/historiageral/as-mulheres-na-historia.htm〉. Acesso em: 25 set. 2019.
} 
admite que a mulher possa alcançar lugares que nem mesmo homens conseguiram, ou, que possam contribuir socialmente tanto quanto eles.

É nesse sentido que se encontra ainda cultivada a violência contra a mulher, a violência de gênero - que apesar de abranger atos praticados por que alguém é homem ou mulher - torna-se muito mais evidente contra esta última, por ter nascido em um sexo subjugado social e culturalmente.

\title{
1.2 VIOLÊNCIA DE GÊNERO
}

A distinção existente entre homens e mulheres é cultural, propagada no decorrer dos anos mesmo como toda a evolução da civilização humana. Em algumas sociedades a mulher é considerada divina, mas de uma forma geral constata-se que é comum em sua maioria, o tratamento como um ser inferior. Como descrito por Liliane Nascimento de Santi, Ana Márcia Spanó Nakano, Angelina Lettiere:

\begin{abstract}
Diante deste fenômeno, presente no espaço social, encontra-se a violência contra a mulher. O primeiro documento internacional de direitos humanos que aborda esta violência foi aprovado em 1993, na Assembléia Geral das Nações Unidas. Esse documento define violência contra a mulher como qualquer ato de violência baseado no gênero que resulta, ou tenha probabilidade de resultar, dano ou sofrimento físico, sexual e psicológico, incluindo ameaça, coação ou privação arbitrária de liberdade, na vida pública ou privada. ${ }^{17}$
\end{abstract}

Percebe-se então que as diferenças no que se refere ao gênero, insurgem contra o indivíduo desde as peculiaridades biológicos. Contudo, não são somente as características que tornam cada ser humano diferente, a cultura social machista propõe que a mulher é diferente apenas por fazer parte desse gênero, ultrapassando os limites biológicos, chegando à desvalorização do gênero em si.

\footnotetext{
17 SANTI, Liliane Nascimento de Santi; NAKANO, Ana Márcia Spanó; LETTIERE. Angelina. Percepção de Mulheres em Situação de Violência sobre o Suporte e Apoio Recebido em seu Contexto Social. Florianópolis, p. 417-424, 2010. p. 418.
} 
Deste modo, importante apresentar o conceito de gênero, Gênero é um recurso utilizado para se referir à construção social desigual baseada na existência de hierarquia entre os sexos e as conseqüências que daí se originam. Essa diferença não é só conceitual, tem efeitos políticos, sociais e culturais. ${ }^{18}$

Nas relações entre os seres humanos verifica-se que as características sexuais predominam e influenciam diretamente os fatores de identificação de papéis socialmente concebidos, bem como nos conceitos pré-definidos por essa cultura patriarcal, mesmo que estejam comprovados que nas mais variadas áreas as tarefas podem ser desenvolvidas de forma igual entre ambos os gêneros.

A violência de gênero exprime a propagação de uma cultura patriarcal, aparentemente longe de terminar, uma vez que mesmo com toda independência que a mulher conquistou, ainda é "objeto" social de dominação.

Não é identidade entre homens e mulheres que queremos reclamar, mas uma diversidade historicamente variável mais complexa do que aquela que é permitida pela oposição macho/fêmea, uma diversidade que é também diferentemente expressada para diferentes propósitos em diferentes contextos. Na verdade, a dualidade criada por essa oposição traça uma linha de diferença, investe-a com explanações biológicas, e então trata cada lado da oposição como fenômeno unitário (...). Em contraste, nossa meta é ver não somente diferenças entre os sexos, mas também o modo como essas trabalham para represar as diferenças dentro dos grupos de gênero. A identidade construída em cada lado da oposição binária esconde o múltiplo jogo de diferenças e mantém sua irrelevância e invisibilidade. ${ }^{19}$

A violência de gênero em um entendimento precípuo reflete qualquer ato violento praticado em detrimento de uma pessoa por conta do sexo a que pertença, seja homem ou mulher. Contudo, no que diz respeito a mulher, essa violência é muito mais notável, a figura feminina é violentada apenas por pertencer a esse gênero, não se pode generalizar, mas é fato que se torna quase impossível tomar conhecimento de que alguém tenha sido agredido por ser homem.

\footnotetext{
${ }^{18}$ FARAH, Marta Ferreira Santos. Gênero e Políticas Públicas. Estudos Feministas, Florianópolis, p. 47-71, janeiro-abril/2004. p. 48.

${ }^{19}$ LOURO, Guacira Lopes. Gênero, história e educação: construção e desconstrução. Educação \& realidade, [S.1.], v. 20, n. 2, 1995. p. 116.
} 
A violência de gênero é ato agressivo em razão da discriminação de sexo, no caso da mulher, pode ser apontada como a classificação a qual se inserem todas as outras formas de violência, uma vez que - não há outro entendimento - se não o de que a mulher é vítima de violência doméstica, sexual, patrimonial, compreendido ainda a violência física, psicológica, tão somente por ser mulher, por ser ainda hoje tratada como objeto e inferior.

Antes de adentrar na violência doméstica é necessário apresentar um dos conceitos que arrastam a subordinação e violência a mulher o conceito de Patriarcalismo:

O patriarcalismo é uma das estruturas sobre as quais se assentam todas as sociedades contemporâneas. Caracteriza-se pela autoridade, imposta institucionalmente, do homem sobre a mulher e filhos no âmbito familiar. Para que essa autoridade possa ser exercida, é necessário que o patriarcalismo permeie toda a organização da sociedade, da produção e do consumo à política, à legislação e à

cultura. Os relacionamentos interpessoais e, consequentemente, a personalidade, também são marcados pela dominação e violência que têm sua origem na cultura e instituições do patriarcalismo. ${ }^{20}$

\subsection{VIOLÊNCIA DOMÉSTICA}

A violência doméstica faz referência a situações violadoras de direitos e da integridade de uma mulher ocorrida no âmbito familiar, praticada por familiares, em geral é situação recorrente do marido para com sua mulher.

Maria Berenice Dias comenta acerca da definição da violência contra a mulher com base nos preceitos legais:

Ainda que a lei não seja a sede adequada para emitir conceitos, andou bem o legislador em definir a violência doméstica (art. $\left.5^{\circ}\right)$ e identificar suas formas (art. $7^{\circ}$ ). A absoluta falta de consciência social do que seja violência domestica e que acabou condenando este crime a invisibilidade. Afinal, a mulher ainda goza de uma posição de menos valia, sua vontade não e respeitada e não tem da liberdade

\footnotetext{
${ }^{20}$ CASTELLS, Manuel. O poder da identidade. São Paulo: Paz e Terra, 2010. p. 169.
} 
de escolha. Aliás, as agressões contra a mulher sequer eram identificadas como violação dos direitos humanos. Dai louvável a iniciativa, que inclusive tem caráter pedagógico. ${ }^{21}$

O conceito expressado pela Lei 11.340/2006 intitulada Lei Maria da Penha, é apontado como genérico e, por não ser especifico, pode levar a interpretação de que qualquer ato violento contra a mulher seria violência doméstica, quando na realidade, essa diz respeito a situações especificas.

Consonante ao que explica Guilherme de Souza Nucci:

Violência doméstica e familiar: violência significa, em linhas gerais, qualquer forma de constrangimento ou força, que pode ser física ou moral. Entretanto, em termos penais, padronizou-se o entendimento de que o termo, quando lançado nos tipos penais incriminadores, tem o condão de representar apenas a violência física. ${ }^{22}$

Em concordância ao comentário de Vera de Andrade:

A agravante inserida no Código Penal (art. 61, II, f, in fine) tem limitado campo de abrangência, pois restringe a violência contra a mulher na forma da lei específica. Assim, somente a violência praticada contra a mulher em razão do convívio familiar ou afetivo é que leva ao aumento da pena. ${ }^{23}$

\footnotetext{
${ }^{21}$ DIAS, Maria Berenice. A Lei Maria da Penha na justiça: a efetividade da Lei 11.340/2006 de combate a violência doméstica e familiar contra a mulher. São Paulo: Revista dos Tribunais, 2007. p. 39.

${ }^{22}$ NUCCI, Guilherme de Souza. Leis penais e processuais penais comentadas. 5. ed. São Paulo: Revista dos Tribunais, 2010. p. 1259.

${ }^{23}$ ANDRADE, Vera Regina Pereira de. Pelas Mãos da Criminologia: O controle penal para além da (des)ilusão. p. 40.
} 


\section{A VIOLÊNCIA CONTRA MULHER}

A violência contra a mulher, na verdade, manifesta-se inicialmente em decorrência do gênero, partindo para ambientes e formas especificas em que pode se desencadear, os mais comuns enumerados são: o ambiente familiar e as relações de trabalho, tendo práticas e fundamentos em comum.

Damásio de Jesus explica a identificação do ambiente como fator de caracterização da ocorrência da violência doméstica:

No lar ou fora dele, desde que haja um relacionamento doméstico, familiar ou íntimo entre os sujeitos. De modo que as normas, quando se referem à violência doméstica, não indicam a relevância do fato praticado nos limites territoriais do lar, dizendo respeito ao âmbito da unidade familiar. Além desse limite conceituai incide a lei comum, não a Lei n. 11.340/2006. ${ }^{24}$

As situações que envolvem a ocorrência de violência doméstica e familiar contra a mulher decorrem de anos de uma cultura que impõe uma subordinação e submissão da figura feminina aos ditames e valores masculinos, como se naturalmente existisse uma hierarquia entre homens e mulheres que devesse ser perpetrada e seguida à risca.

A violência contra mulher é descrita por Amini Haddad Campos e Lindinalva Rodrigues Corrêa:

Descreve alguns fatores que contribuem para a prática da violência contra a mulher, sendo estes: a falta de punição dos agressores, o silêncio das mulheres agredidas, a inferioridade das mulheres e a transformação das vítimas em culpadas. Portanto, a violência contra a mulher representa um verdadeiro desrespeito aos direitos e garantias fundamentais da mulher, colocando-se como um obstáculo para a efetivação de uma série de princípios constitucionais, tais como a dignidade da pessoa humana, da igualdade, da liberdade, dentre outros. Assim sendo, a Lei Maria da Penha - Lei no 11.340/06 representa um marco na proteção aos direitos das mulheres, pois, de

24 JESUS, Damásio de. Violência Contra a Mulher: aspectos criminais da Lei n. 11.340/2006. 2. ed. São Paulo: Saraiva, 2015. 
maneira geral teve como premissa essencial coibir e prevenir todas as formas de violência doméstica e familiar, nos termos do artigo 226 da Constituição Federal de 1988, da Convenção sobre a Eliminação de Todas as Formas de Discriminação Contra as Mulheres e da Convenção Interamericana para Prevenir, Punir e Erradicar a Violência Contra a Mulher, ratificado pelo Brasil. No período anterior à Lei, de 1980 até 2006, o crescimento do número de homicídios de mulheres foi de $7,6 \%$ ao ano. Já no período de 2006 até 2013, após a vigência da Lei, decresce o número desses homicídios para 2,6\% ao ano e das taxas para $1,7 \%$ ao ano. ${ }^{25}$

\subsection{FORMAS DE VIOLÊNCIA CONTRA A MULHER}

Não é novidade que, em âmbito internacional, as culturas patriarcais mantêm em comum, comportamentos que desmerecem a figura feminina, a violência de gênero de forma clara é em geral praticada contra a mulher, apenas por pertencer ao sexo feminino.

O que se pode ilustrar nas palavras de Simone Beauvior:

$\mathrm{Na}$ boca do homem o epíteto "fêmea" soa como um insulto; no entanto, ele não se envergonha de sua animalidade, sente-se, ao contrário, orgulhoso se dele dizem: "É um macho!" O termo "fêmea" é pejorativo, não porque enraíze a mulher na natureza, mas porque a confina no seu sexo. ${ }^{26}$

Analisa-se neste tópico as formas nominadas de violência que tem como vítima a mulher, principalmente a que ocorre no âmbito doméstico, o abuso sexual, as marcas e traumas as quais a vítima é exposta, mesmo com previsões legais que visam coibir essas ocorrências.

A violência contra a mulher, de forma específica - mas que acontece em regra geral contra qualquer indivíduo - pode ser definida como atos propagados contra indivíduo do sexo feminino que lhe violam a integridade psicológica, moral, sexual, física, patrimonial e em estágio mais gravoso, chega à morte desta.

${ }^{25}$ CAMPOS, Amini Haddad; CORRÊA, Lindinalva Rodrigues. Direitos Humanos das Mulheres. Curitiba: Juruá, 2012.

${ }^{26}$ BEAUVOIR, Simone. O Segundo sexo: fatos e mitos; tradução de Sérgio Milliet. 4 ed. São Paulo: Difusão Européia do Livro, 1980. 
A conduta violenta contra a mulher pode ser omissiva ou comissiva, onde se constata a ocorrência de agressão, discriminação, coerção, que levam a danos fisiológicos, emocionais, psicológicos, patrimoniais, entre outros, podendo ocorrer em locais públicos ou privados. ${ }^{27}$

O Conselho Nacional de Justiça aponta as seguintes formas de violência contra a mulher:

Violência de gênero - violência sofrida pelo fato de se ser mulher, sem distinção de raça, classe social, religião, idade ou qualquer outra condição, produto de um sistema social que subordina o sexo feminino. Violência doméstica - quando ocorre em casa, no ambiente doméstico, ou em uma relação de familiaridade, afetividade ou coabitação. Violência familiar - violência que acontece dentro da família, ou seja, nas relações entre os membros da comunidade familiar, formada por vínculos de parentesco natural (pai, mãe, filha etc.) ou civil (marido, sogra, padrasto ou outros), por afinidade (por exemplo, o primo ou tio do marido) ou afetividade (amigo ou amiga que more na mesma casa). Violência física - ação ou omissão que coloque em risco ou cause dano à integridade física de uma pessoa. Violência institucional - tipo de violência motivada por desigualdades (de gênero, étnico-raciais, econômicas etc.) predominantes em diferentes sociedades. Essas desigualdades se formalizam e institucionalizam nas diferentes organizações privadas e aparelhos estatais, como também nos diferentes grupos que constituem essas sociedades. Violência intrafamiliar/violência doméstica - acontece dentro de casa ou unidade doméstica e geralmente é praticada por um membro da família que viva com a vítima. As agressões domésticas incluem: abuso físico, sexual e psicológico, a negligência e o abandono. Violência moral - ação destinada a caluniar, difamar ou injuriar a honra ou a reputação da mulher. Violência patrimonial ato de violência que implique dano, perda, subtração, destruição ou retenção de objetos, documentos pessoais, bens e valores. Violência psicológica - ação ou omissão destinada a degradar ou controlar as ações, comportamentos, crenças e decisões de outra pessoa por meio de intimidação, manipulação, ameaça direta ou indireta, humilhação, isolamento ou qualquer outra conduta que implique prejuízo à saúde psicológica, à autodeterminação ou ao desenvolvimento pessoal. Violência sexual - acão que obriga uma pessoa a manter contato sexual, físico ou verbal, ou a participar de outras relações sexuais com uso da força, intimidação, coerção, chantagem, suborno, manipulação, ameaça ou qualquer outro mecanismo que anule ou limite a vontade pessoal. Considera-se como violência sexual também o fato de o agressor obrigar a vítima a realizar alguns desses atos com terceiros. Consta ainda do Código Penal Brasileiro: a violência sexual pode ser caracterizada de forma

\footnotetext{
${ }^{27}$ FORMAS de violência contra a mulher. Informação postada no site do Conselho Nacional de Justiça (CNJ), no hiperlink Programas e ações: Lei Maria da Penha, Disponível em: <https://www.cnj.jus.br/programas-eacoes/lei-maria-da-penha/formas-de-violencia>. Acesso em: 01 set. 2019.
} 
física, psicológica ou com ameaça, compreendendo o estupro, a tentativa de estupro, o atentado violento ao pudor e o ato obsceno. ${ }^{28}$

Em uma análise sociológica percebe-se que a violência contra a mulher foi legitimada principalmente no ambiente familiar, onde os números mostram sua grande recorrência, essa situação em muitos lugares já é imposta desde o nascimento.

Nos subtópicos a seguir faz-se breve descrição acerca das formas de violência contra a mulher.

\subsubsection{A Violência Psicológica e Moral}

Estuda-se essas duas modalidades de violência de forma concomitante tendo em vista que a moral intrinsecamente está ligada ao psicológico de uma pessoa, vez que se trata de um estado, uma noção de percepção de sua própria imagem perante a sociedade e para si, ligada as noções do que sabe ser certo, errado, vexatório ou outro sentimento.

No artigo $7^{0}$, II e V da Lei 11.340/2006 a violência psicológica e moral é prevista da seguinte forma:

Art. 7º. São formas de violência doméstica e familiar contra a mulher, entre outras:

$[\ldots]$

II - a violência psicológica, entendida como qualquer conduta que the cause dano emocional e diminuição da auto-estima ou que the prejudique e perturbe o pleno desenvolvimento ou que vise degradar ou controlar suas ações, comportamentos, crenças e decisões, mediante ameaça, constrangimento, humilhação, manipulação, isolamento, vigilância constante, perseguição contumaz, insulto, chantagem, ridicularização, exploração e limitação do direito de ir e vir ou qualquer outro meio que lhe cause prejuízo à saúde psicológica e à autodeterminação;

$[\ldots]$

\footnotetext{
${ }^{28}$ FORMAS de violência contra a mulher. Informação postada no site do Conselho Nacional de Justiça (CNJ), no hiperlink Programas e ações: Lei Maria da Penha, Disponível em: <https://www.cnj.jus.br/programas-eacoes/lei-maria-da-penha/formas-de-violencia>. Acesso em: 01 set. 2019.
} 
V - a violência moral, entendida como qualquer conduta que configure calúnia, difamação ou injúria. ${ }^{29}$

As formas como ocorrem a violência psicológica e moral ainda não são totalmente compreendidas, inclusive é notório que as "doenças" voltadas a essa ainda são relativizadas, contudo, é certo o entendimento que a violação a integridade dessas áreas traz efeitos, as vezes muito maiores, dos que os que ocorrem na esfera física.

Essa conclusão tem fundamento mais sólido quando se percebe que a cultura da sociedade - em grande parte - ainda é machista, julgando como errado a mulher requerer os direitos e a igualdade que lhe é assegurada, bem como a forma como se comporta, fala, anda, as suas vestimentas. Como se esses itens fossem requisitos autorizadores da violência.

Maria Berenice Dias aponta:

A violência psicológica encontra forte alicerce nas relações desiguais de poder entre os sexos. É a mais freqüente e talvez seja a menos denunciada. A vítima muitas vezes nem se dá conta que agressões verbais, silêncios prolongados, tensões, manipulações de atos e desejos, são violências e devem ser denunciados. Para a configuração do dano psicológico não é necessária a elaboração de laudo técnico ou realização de perícia. ${ }^{30}$

Essas modalidades de violência estão intimamente ligadas à cultura, que mesmo em um mundo evoluído, as mulheres são submetidas a situações degradantes, humilhações, maridos e pais que exercem um terrorismo psicológico contra suas mulheres e filhas, formando jovens e adultas inseguras, traumatizadas, estigmatizadas por uma sociedade que simplesmente as enxergam como sexo frágil e cumpridora de tarefas domésticas, muitas vezes não tendo, sequer, forças para resistir e se livrar de condutas violentas.

\footnotetext{
${ }^{29}$ BRASIL. Lei n. 11.340, de 7 de agosto de 2006. Cria mecanismos para coibir a violência doméstica e familiar contra a mulher, nos termos do $\S 80$ do art. 226 da Constituição Federal, da Convenção sobre a Eliminação de Todas as Formas de Discriminação contra as Mulheres e da Convenção Interamericana para Prevenir, Punir e Erradicar a Violência contra a Mulher; dispõe sobre a criação dos Juizados de Violência Doméstica e Familiar contra a Mulher; altera o Código de Processo Penal, o Código Penal e a Lei de Execução Penal; e dá outras providências. Disponível em: <http://www.planalto.gov.br/ccivil_03/_ato20042006/2006/lei/111340.htm>. Acesso em: 15 set. 2019.

${ }^{30}$ DIAS, Maria Berenice. A Lei Maria da Penha na justiça: a efetividade da Lei 11.340/2006 de combate à violência doméstica e familiar contra a mulher. São Paulo: Revista dos Tribunais, 2007. p. 48.
} 
Luana Manzini comenta acerca da violência psicológica:

Os atos de violência psicológica tendem a abalar a qualidade de vida da vítima, que sofrendo constante humilhação, por meio de agressões à sua personalidade, opiniões, características e formação, pode desencadear doenças, como úlceras, gastrite nervosa, enxaqueca, depressão, síndrome do pânico, transtornos psicológicos, dependência medicamentosa ou psicotrópica, causando-a, inclusive, morte. A violência psicológica inicia-se de forma branda, com atos que passam despercebidos pela vítima, onde o agressor lança mão de pequenos insultos a fim de tornar a vítima insegura e baixar sua autoestima, bem porque, para partir para agressão física, o agressor precisa tornar a mulher desvalorizada de tal modo que ela aceite a agressão e se sinta culpada pela violência sofrida. Assim, o agressor passa a dissuadir a mulher, visando que esta, manifestamente vulnerável, torne-se emocionalmente dependente e aja conforme sua vontade, acatando suas decisões e aceite o tratamento a ela despendido. Com o passar do tempo, o agressor passa a manifestar-se de forma mais notória, com humilhações privadas ou públicas, expondo a mulher a situações vexatórias, ridicularizando seu corpo, atribuindo apelidos depreciativos e criticando suas características pessoais, a fim de the causar sofrimento. ${ }^{31}$

É nesse campo que se pode compreender a ocorrência de violência psicológica e moral desde a concepção, quando um pai rejeita o filho por nascer mulher, quando o marido, após o casamento revela-se possessivo e agressor em seu tratamento fazendo com que a esposa acredite ter sua existência dependente dele.

Constata-se ainda, a ocorrência dessas modalidades de violência em decorrência de violência sexual e física.

\footnotetext{
${ }^{31}$ MANZINI, Luana. Violência psicológica contra mulheres: uma abordagem com os instrumentos previstos na Lei Maria da Penha. In.: Jus.com.br, [s.n.: S.l.], nov. 2016. Disponível em: $<$ https://jus.com.br/artigos/64779/violencia-psicologica-contra-mulheres-uma-abordagem-com-osinstrumentos-previstos-na-lei-maria-da-penha/1>. Acesso em: 10 set. 2019.
} 


\subsubsection{A Violência Sexual}

A violência contra a mulher na esfera sexual pode ser compreendida como um silencioso de manifestar o ato violento, já que muitas vezes não deixa sequer vestígios e, a vítima carrega consigo a "vergonha" de ter passado por essa situação.

Não desconhecidas são as sociedades que cultivam a cultura de promoção ao estupro, a violência sexual é "autorizada", a exemplo disso se relata a história de duas irmãs na índia "condenadas" ao estupro coletivo por seu irmão ter se relacionado e fugido com uma mulher casada de casta superior. ${ }^{32}$

O ordenamento jurídico brasileiro disciplina de forma especifica a ocorrência de violência sexual contra a mulher no artigo $7^{\circ}$, III, da Lei 11.340/2006:

Art. $7^{0}$ São formas de violência doméstica e familiar contra a mulher, entre outras: [...]

III - a violência sexual, entendida como qualquer conduta que a constranja a presenciar, a manter ou a participar de relação sexual não desejada, mediante intimidação, ameaça, coação ou uso da força; que a induza a comercializar ou a utilizar, de qualquer modo, a sua sexualidade, que a impeça de usar qualquer método contraceptivo ou que a force ao matrimônio, à gravidez, ao aborto ou à prostituição, mediante coação, chantagem, suborno ou manipulação; ou que limite ou anule o exercício de seus direitos sexuais e reprodutivos; ${ }^{33}$

A mencionada previsão está em conformidade ao que já era tutelado pelo Código Penal na classe dos crimes contra a honra:

\footnotetext{
${ }^{32}$ IRMÃS Indianas Condenadas a Estupro Coletivo Temem Vingança, Caso Voltem à Aldeia. [s.n.: S.l.], 02 set. 2015. Informação postada no site O Globo. Disponível: <http://oglobo.globo.com/sociedade/irmas-indianascondenadas-estupro-coletivo-temem-vinganca-caso-voltem-aldeia-17378003>. Acesso em: 02 set. 2019.

${ }^{33}$ BRASIL. Lei n. 11.340, de 7 de agosto de 2006. Cria mecanismos para coibir a violência doméstica e familiar contra a mulher, nos termos do $\S 80$ do art. 226 da Constituição Federal, da Convenção sobre a Eliminação de Todas as Formas de Discriminação contra as Mulheres e da Convenção Interamericana para Prevenir, Punir e Erradicar a Violência contra a Mulher; dispõe sobre a criação dos Juizados de Violência Doméstica e Familiar contra a Mulher; altera o Código de Processo Penal, o Código Penal e a Lei de Execução Penal; e dá outras providências. Disponível em: <http://www.planalto.gov.br/ccivil_03/_ato20042006/2006/lei/111340.htm>. Acesso em: 15 set. 2019.
} 


\section{Estupro}

Art. 213. Constranger alguém, mediante violência ou grave ameaça, a ter conjunção carnal ou a praticar ou permitir que com ele se pratique outro ato libidinoso:

Pena - reclusão, de 6 (seis) a 10 (dez) anos.

$\S 1^{\circ}$ Se da conduta resulta lesão corporal de natureza grave ou se a vítima é menor de 18 (dezoito) ou maior de 14 (catorze) anos:

Pena - reclusão, de 8 (oito) a 12 (doze) anos.

$\S 2^{\circ}$ Se da conduta resulta morte:

Pena - reclusão, de 12 (doze) a 30 (trinta) anos.

[...]

Violação sexual mediante fraude

Art. 215. Ter conjunção carnal ou praticar outro ato libidinoso com alguém, mediante fraude ou outro meio que impeça ou dificulte a livre manifestação de vontade da vítima:

Pena - reclusão, de 2 (dois) a 6 (seis) anos.

Parágrafo único. Se o crime é cometido com o fim de obter vantagem econômica, aplica-se também multa.

[...]

Assédio sexual

Art. 216-A. Constranger alguém com o intuito de obter vantagem ou favorecimento sexual, prevalecendo-se o agente da sua condição de superior hierárquico ou ascendência inerentes ao exercício de emprego, cargo ou função."

Pena - detenção, de 1 (um) a 2 (dois) anos.

$\S 2$ - A pena é aumentada em até um terço se a vítima é menor de 18 (dezoito) anos. ${ }^{34}$

Essa forma de violência consubstancia desde atos assediadores até a conjunção carnal contra a vontade da vítima, atualmente incluídas no tipo penal mais gravoso que é o estupro.

Nesse sentido disciplina Maria Berenice Dias:

Os delitos equivocadamente chamados de "contra os costumes" constituem, às claras, violência sexual. Quem obriga uma mulher a manter relação sexual não desejada pratica o crime sexual de estupro. Também os outros crimes contra a liberdade sexual configuram violência sexual quando praticados contra a mulher: atentado violento ao pudor; posse sexual mediante fraude; atentado ao pudor mediante fraude; assédio sexual e corrupção de menores. ${ }^{35}$

\footnotetext{
${ }^{34}$ BRASIL. Decreto-Lei n. 2.848, de 7 de dezembro de 1940. Institui o Código Penal. Disponível em: <http://www.planalto.gov.br/ccivil_03/decreto-lei/Del2848compilado.htm>. Acesso em: 10 set. 2019.

${ }^{35}$ DIAS, Maria Berenice. A Lei Maria da Penha na justiça: a efetividade da Lei 11.340/2006 de combate a violência doméstica e familiar contra a mulher. São Paulo: Editora Revista dos Tribunais, 2007. p. 49.
} 
No dossiê elaborado sobre a violência sexual contra a mulher pelo Instituto Patrícia Galvão tem-se o seguinte apontamento sobre tal forma de violência, fazendo relação ainda, com a ligação entre a violência psicológica ocorrida como sequela do ato sexual violador:

O estupro ainda vitima milhares de mulheres de todas as idades cotidianamente no Brasil e no mundo. Suas consequências para as vítimas são severas e devastadoras: a violência sexual tem sérios efeitos nas esferas física e mental, no curto e longo prazos, [...]Segundo o estudo, entre as consequências físicas imediatas estão a gravidez, infecções do aparelho reprodutivo e doenças sexualmente transmissíveis (DSTs). Em longo prazo, as mulheres podem desenvolver distúrbios na esfera da sexualidade, apresentando ainda maior vulnerabilidade para sintomas psiquiátricos, principalmente depressão, pânico, somatização, tentativa de suicídio, abuso e dependência de substancias psicoativas. ${ }^{36}$

A ocorrência do estupro é situação que coloca temor em toda a sociedade, mas, no que se refere a mulher tem proporções ainda maiores, a mulher infelizmente é "culpabilizada" por ser vítima, julgam-se seus comportamentos, suas vestimentas, o local em que estava. Muitas mulheres deixam de sair, de fazer o que desejam por medo de que ocorram situações como essa.

\subsubsection{A Violência Patrimonial}

A violência patrimonial a tempos atrás não tinha sua exata existência compreendida, atualmente vem crescendo relatos de ocorrência em que se constatam as vantagens obtidas de uma mulher sob ameaças, agressões, chantagens, entre outros.

Aponta-se como violência patrimonial os casos em que as mulheres são submetidas a situações de assaltos, sequestros e meios criminosos. Conforme prescreve Rogério da Cunha Pereira:

\footnotetext{
${ }^{36}$ VIOLÊNCIA Sexual. [S.n.t.]. Informação postada no site Dossiê Violência Contra as Mulheres, do Instituto Patrícia Galvão. Disponível em: <https://dossies.agenciapatriciagalvao.org.br/violencia/violencias/violenciasexual/>. Acesso em: 10 set. 2019.
} 
[...] a violência patrimonial se caracteriza quando a parte econômica mais forte na relação conjugal, e na maioria das vezes após o seu fim, usa e abusa de seu poder e domínio da administração dos bens de propriedade comum, não repassando ao outro os frutos dos bens conjugais, gerando uma situação de opressão, dominação e abuso de poder sobre o outro. ${ }^{37}$

A Lei Maria da Penha estabelece em seu artigo $7^{\circ}$, IV a violência patrimonial como sendo: "qualquer conduta que configure retenção, subtração, destruição parcial ou total de seus objetos, instrumentos de trabalho, documentos pessoais, bens, valores e direitos ou recursos econômicos, incluindo os destinados a satisfazer suas necessidades". ${ }^{38}$

Consoante aos tipos penais mais genéricos trazidos pelo Código Penal tais como: furto (artigo 155), roubo (artigo 157), extorsão (artigo 158). ${ }^{39}$

Maria Berenice Dias comenta que um conceito mais atual de violência doméstica trouxe maior abrangência inclusive a ocorrência de violência patrimonial, a saber:

\begin{abstract}
A partir da nova definição de violência doméstica, assim reconhecida também a violência patrimonial, não se aplicam as imunidades absolutas ou relativas dos arts. 181 e 182 do Código Penal quando a vítima é mulher e mantém com o autor da infração vínculo de natureza familiar. Não há mais como admitir o injustificável afastamento da pena ao infrator que pratica um crime contra sua cônjuge ou companheira, ou, ainda, alguma parente do sexo feminino. Aliás, o Estatuto do Idoso, além de dispensar a representação, expressamente prevê a não aplicação desta excludente da criminalidade quando a vítima Li ver mais de 60 anos. A Lei Maria da Penha reconhece como violência patrimonial o ato de "subtrair" objetos da mulher, o que nada mais é do que furtar. Assim,
\end{abstract}

37 PEREIRA, Rogério da Cunha. O que é violência patrimonial contra a mulher?. [s.n.: S.1.], 22 nov. 2018. Informação postada no site Rodrigo da Cunha Pereira. Disponível em: <http://www.rodrigodacunha.adv.br/o-que-e-violencia-patrimonial-contra-mulher/>. Acesso em: 15 set. 2019.

${ }^{38}$ BRASIL. Lei n. 11.340, de 7 de agosto de 2006. Cria mecanismos para coibir a violência doméstica e familiar contra a mulher, nos termos do $\S 80$ do art. 226 da Constituição Federal, da Convenção sobre a Eliminação de Todas as Formas de Discriminação contra as Mulheres e da Convenção Interamericana para Prevenir, Punir e Erradicar a Violência contra a Mulher; dispõe sobre a criação dos Juizados de Violência Doméstica e Familiar contra a Mulher; altera o Código de Processo Penal, o Código Penal e a Lei de Execução Penal; e dá outras providências. Disponível em: <http://www.planalto.gov.br/ccivil_03/_ato20042006/2006/lei/111340.htm>. Acesso em: 15 set. 2019.

39 BRASIL. Decreto-Lei n. 2.848, de 7 de dezembro de 1940. Institui o Código Penal. Disponível em: <http://www.planalto.gov.br/ccivil_03/decreto-lei/Del2848compilado.htm>. Acesso em: 10 set. 2019. 
se subtrair para si coisa alheia móvel configura o delito de furto, quando a vítima é mulher com quem o agente mantém relação de ordem afetiva, não se pode mais reconhecer a possibilidade de isenção da pena. ${ }^{40}$

No âmbito doméstico como ser noticiada nos relatos de maridos que "vivem às custas" da mulher, com atos contra sua integridade psicológica, fazendo com essas se vejam como dependentes dos mesmos, em desconsideração a sua verdadeira realidade.

\subsubsection{Violência Física}

A violência física deixa vestígios, é o comportamento mais comum a ser notado e também aquele tido como normal, uma vez que se justifica que todo mundo já ultrapassou seus limites e surtou alguma vez na vida.

O artigo $7^{\circ}$, I e IV da Lei 11.340/2006 disciplina de forma específica essa violência física:

Art. $7^{0}$ São formas de violência doméstica e familiar contra a mulher, entre outras:

I - a violência física, entendida como qualquer conduta que ofenda sua integridade ou saúde corporal; [...]

IV - a violência patrimonial, entendida como qualquer conduta que configure retenção, subtração, destruição parcial ou total de seus objetos, instrumentos de trabalho, documentos pessoais, bens, valores e direitos ou recursos econômicos, incluindo os destinados a satisfazer suas necessidades; ${ }^{41}$

\footnotetext{
${ }^{40}$ DIAS, Maria Berenice. A Lei Maria da Penha na justiça: a efetividade da Lei 11.340/2006 de combate a violência doméstica e familiar contra a mulher. São Paulo: Revista dos Tribunais, 2007. p. 52.

${ }^{41}$ BRASIL. Lei n. 11.340, de 7 de agosto de 2006. Cria mecanismos para coibir a violência doméstica e familiar contra a mulher, nos termos do $\S 80$ do art. 226 da Constituição Federal, da Convenção sobre a Eliminação de Todas as Formas de Discriminação contra as Mulheres e da Convenção Interamericana para Prevenir, Punir e Erradicar a Violência contra a Mulher; dispõe sobre a criação dos Juizados de Violência Doméstica e Familiar contra a Mulher; altera o Código de Processo Penal, o Código Penal e a Lei de Execução Penal; e dá outras providências. Disponível em: <http://www.planalto.gov.br/ccivil_03/_ato20042006/2006/lei/l11340.htm>. Acesso em: 15 set. 2019.
} 
Prevista também no Código Penal, porém de forma genérica, a violência física é tipificada penalmente a partir do artigo 129 que prevê a ocorrência e sanção da lesão corporal. 42

A respeito da violência física não faltam notícias de que mulheres são agredidas aos montes, principalmente em âmbito familiar. Agressões essas que em muitos casos terminam com a ocorrência de feminicídio, em que após tantos atos físicos violentos, a vítima acaba por perder sua vida.

42 BRASIL. Decreto-Lei n. 2.848, de 7 de dezembro de 1940. Código Penal. Disponível em: <http://www.planalto.gov.br/ccivil_03/decreto-lei/Del2848compilado.htm>. Acesso em: 10 set. 2019. 


\section{FEMINICÍDIO: A RELAÇÃO ENTRE VIOLÊNCIA DE GÊNERO E VIOLÊNCIA DOMÉSTICA}

\subsection{A LEI MARIA DA PENHA}

A Constituição Federal de $1988^{43}$ é reconhecida como sendo uma carta cidadã, consolidou no cenário jurídico brasileiro proteção a direitos considerados fundamentais e essenciais a vida humana, priorizando a proteção a dignidade através de garantias às prerrogativas que lhe são inerentes.

Nesse contexto, tem-se que um dos avanços merecidamente reconhecidos e disciplinados trata da igualdade entre todos, sem distinções, da igualdade entre cônjuges, entre genitores, do direito da mulher ao voto, a licença maternidade, a proteção como trabalhadora, entre tantos outros.

Contudo, apesar de todas as previsões protetivas e igualitárias em relação a mulher, essa ainda continua sendo vítima de violência e desigualdade social, atos violadores praticados e mantidos culturalmente principalmente no seio familiar, sem instrumentos que tenham a devida efetividade na diminuição desses números.

A respeito do contexto de criação e promulgação de uma lei especificamente voltada à violência contra mulher, Myllena Calazans disserta:

O processo para a criação de uma lei especial de combate à violência doméstica e familiar contra as mulheres no Brasil foi muito longo e antecipado de muitas manifestações e debates. Na década de setenta, quando grupos de mulheres foram às ruas com o slogan quem ama não mata, levantou-se de forma enérgica a bandeira contra a violência, sendo este tema incluído na pauta feminista como uma de suas principais reivindicações. Grupos foram formados, manifestações foram feitas e a luta para ver punidos os assassinos foram iniciadas. Um dos casos mais emblemáticos daquela época foi o de Doca Street, que assassinou sua companheira e no Tribunal de Júri alegou "legítima defesa da honra", alegação até hoje usada por advogados que tentam livrar assassinos da punição (Brazão e

\footnotetext{
${ }^{43}$ BRASIL. (Constituição 1988). Constituição da República Federativa do Brasil de 1988. Disponível em: <http://www.planalto.gov.br/ccivil_03/constituicao/ConstituicaoCompilado.htm>. Acesso em: 15 out. 2019.
} 
Oliveira, 2010: 19). Inicia-se, na década de oitenta, as primeiras ações governamentais no sentido de incluir em sua agenda a temática da violência contra as mulheres e, em 1985, é criada a primeira delegacia especializada de atendimento às mulheres, fruto da luta do movimento de mulheres. Nos anos noventa, as feministas se mobilizavam de forma mais contundente. Organizaram seminários e reuniões em que a questão da violência era o foco principal. No Congresso Nacional existiam alguns projetos de Lei de iniciativa de parlamentares, de um modo geral voltados para aplicação de medidas punitivas e/ou ações pontuais. Nesse período, a representação feminina no Congresso era pequena e a ação ainda não parecia prioritária para 0 Executivo. Esses fatores foram determinantes para a permanência da lacuna legislativa. ${ }^{44}$

A Lei $11.340 / 200645$, conhecida como Lei Maria da Penha, foi promulgada nesse contexto de acalorados debates acerca de formas legais que possam punir, coibir e prevenir a violência contra a mulher, uma vez que os casos envolvendo essa situação se arrastavam por anos sem solução prática.

Esse dispositivo foi produto, ainda, de situação que permaneceu inerte e sem solução por mais de vinte anos, colocando o Brasil no banco dos réus das cortes internacionais para ser condenado por sua morosidade em resolver o caso.

Conforme narra Myllena Calazans:

Mencione-se ainda, as recomendações da CIDH ao caso Maria da Penha Maia Fernandes, por não cumprimento do previsto no artigo 7. da Convenção de Belém do Pará e nos artigos 1ํ, 8o e 25 da Convenção Americana de Direitos Humanos, e ainda, o dever do Estado brasileiro de indenizar a vítima, monetária e simbolicamente. Ademais, a Comissão recomendou que o Brasil adotasse várias medidas de combate à violência contra a mulher, entre elas, a elaboração de uma lei específica para este fim. Desse modo, a Presidência da República, com assessoria da SPM, decidiu, ao sancionar a Lei aprovada no Congresso Nacional, cumprir a recomendação da OEA, nominando a nova lei de Lei Maria da Penha, como uma forma simbólica de cumprir as recomendações da Comissão. A sanção foi um grande evento no Palácio do Planalto,

\footnotetext{
${ }^{44}$ CALAZANS, Myllena. O processo de criação, aprovação e implementação da Lei Maria da Penha. In.: CAMPOS, Carmen Hein de (org.) Lei Maria da Penha comentada em uma perspectiva jurídico-feminista. Rio de Janeiro: Lumen Juris, 2011, p. 39.

${ }^{45}$ BRASIL. Lei n. 11.340, de 7 de agosto de 2006. Cria mecanismos para coibir a violência doméstica e familiar contra a mulher, nos termos do $\S 80$ do art. 226 da Constituição Federal, da Convenção sobre a Eliminação de Todas as Formas de Discriminação contra as Mulheres e da Convenção Interamericana para Prevenir, Punir e Erradicar a Violência contra a Mulher; dispõe sobre a criação dos Juizados de Violência Doméstica e Familiar contra a Mulher; altera o Código de Processo Penal, o Código Penal e a Lei de Execução Penal; e dá outras providências. Disponível em: <http://www.planalto.gov.br/ccivil_03/_ato20042006/2006/lei/l11340.htm>. Acesso em: 15 out. 2019.
} 
com a presença de várias autoridades, representantes do movimento de mulheres, e da Senhora Maria da Penha Fernandes, escolhida como um símbolo da luta contra violações dos direitos humanos das mulheres. ${ }^{46}$

Até a promulgação da lei em comento, o caminho foi árduo, marcado por manifestações dos movimentos ligados a confecção dos projetos de lei que visavam instituir esse mecanismo, até o posicionamento direto da Corte Internacional de Direitos Humanos.

O Conselho Nacional de Justiça traz a seguinte explanação sobre o contexto de criação e promulgação da Lei Maria da Penha:

\begin{abstract}
A Lei n. 11.340, sancionada em 7 de agosto de 2006, passou a ser chamada Lei Maria da Penha em homenagem à mulher cujo marido tentou matá-la duas vezes e que desde então se dedica à causa do combate à violência contra as mulheres. $O$ texto legal foi resultado de um longo processo de discussão a partir de proposta elaborada por um conjunto de ONGs (Advocacy, Agende, Cepia, Cfemea, Claden/IPÊ e Themis). Esta proposta foi discutida e reformulada por um grupo de trabalho interministerial, coordenado pela Secretaria Especial de Políticas para as Mulheres (SPM), e enviada pelo Governo Federal ao Congresso Nacional. Foram realizadas audiências públicas em assembleias legislativas das cinco regiões do país, ao longo de 2005, que contaram com participação de entidades da sociedade civil, parlamentares e SPM. A partir desses debates, novas sugestões foram incluídas em um substitutivo. $O$ resultado dessa discussão democrática foi a aprovação por unanimidade no Congresso Nacional. Em vigor desde o dia 22 de setembro de 2006, a Lei Maria da Penha dá cumprimento à Convenção para Prevenir, Punir, e Erradicar a Violência contra a Mulher, a Convenção de Belém do Pará, da Organização dos Estados Americanos (OEA), ratificada pelo Brasil em 1994, e à Convenção para Eliminação de Todas as Formas de Discriminação contra a Mulher (Cedaw), da Organização das Nações Unidas (ONU). ${ }^{47}$
\end{abstract}

De fato, Maria da Penha Maia Fernandes representa as inúmeras vítimas que foram e são todos os dias tratadas como culpadas por uma sociedade com raízes extremamente machistas que não se conforma com o espaço e notoriedade que

\footnotetext{
${ }^{46}$ CALAZANS, Myllena. O processo de criação, aprovação e implementação da Lei Maria da Penha In.: CAMPOS, Carmen Hein de (org.) Lei Maria da Penha comentada em uma perspectiva jurídico-feminista. Rio de Janeiro: Lumen Juris, 2011, p. 56

${ }^{47}$ LEI Maria da Penha. [S.n.t.]. Informação postada no site do Conselho Nacional de Justiça (CNJ). Disponível em: <https://www.cnj.jus.br/lei-maria-da-penha/>. Acesso em: 15 out. 2019.
} 
uma mulher pode ter, com a exposição de vontades e com sua conduta de sujeito de direitos, uma sociedade que ainda vê a mulher como um objeto.

Maria da Penha, brasileira, casada, farmacêutica bioquímica, mesmo no alcance de seus objetivos de vida foi tratada cruelmente durante seis anos por seu marido, sendo submetida a terrível situação que é a violência doméstica, que é a violência por ser mulher e corresponder totalmente ao contrário do ideal que a sociedade tem para pessoas do sexo feminino, em 1983 o marido de Maria da Penha não satisfeito com a vida de violência, agrediu sua mulher até que pudesse tirar-Ihe a vida, situação que a condicionou passar o resto de seus dias com sequelas, ficando paraplégica. ${ }^{48}$

Não satisfeito com o resultado, quando voltou a sua casa Maria da Penha novamente foi vítima de uma tentativa de - então - homicídio, quando seu exmarido tentou eletrocutá-la.

Acerca do histórico de violência enfrentado por Maria da Penha, Maria Berenice Dias aponta:

Como muitas outras mulheres ela reiteradamente denunciou as agressões que sofreu. Chegou a ficar com vergonha de dizer que tinha sido vítima da violência doméstica e pensava: se não aconteceu nada até agora, é porque ele, o agressor, tinha razão de ter jeito aquilo. Mas, ainda assim, não se calou Em face da inércia da Justiça Maria da Penha escreveu um livro uniu-se ao movimento de mulheres e, como ela mesmo diz, não perdeu nenhuma oportunidade de manifestar sua indignação. ${ }^{49}$

Atualmente tem seu merecido lugar no reconhecimento como sendo um dos dispositivos de grande importância na luta contra a violência contra mulher e desigualdade de gênero, mas nesse campo ainda existem situações que comprovam a falta de eficácia quanto a sua aplicação.

No entanto, em que pese a importância da Lei Maria da Penha, altos são os índices de mulheres que sofrem com a violência doméstica, muitas, mesmo transpondo as barreiras da vergonha e exposição, acabam perdendo suas vidas

\footnotetext{
${ }^{48}$ BEZERRA, Juliana. Lei Maria da Penha. [S.n.t.]. Informação postada no site Toda Matéria. Disponível em: <https://www.todamateria.com.br/lei-maria-da-penha/>. Acesso em: 15 out. 2019.

${ }^{49}$ DIAS, Maria Berenice. A Lei Maria da Penha na justiça: a efetividade da Lei 11.340/2006 de combate a violência doméstica e familiar contra a mulher. São Paulo: Revista dos Tribunais, 2007. p. 13.
} 
porque todas as medidas contra seu agressor são solicitadas sem efetividade prática.

\subsubsection{Ampliam-se as Leis de Proteção das Mulheres Vítimas de Violência}

Textos foram apresentados por deputados. Um permite a apreensão de arma registrada em nome do agressor, o outro garante prioridade para vítimas matricularem filhos em escolas perto de casa

Duas leis que alteram a Lei Maria da Penha para ampliar a proteção à vítima de violência doméstica foram sancionadas sem vetos pelo presidente da República, Jair Bolsonaro em outubro de 2019.50

Originada no Projeto de Lei 17/19, do deputado Alessandro Molon (PSB-RJ) e outros nove deputados, a Lei 13.880/19 permite ao juiz ordenar a apreensão de arma de fogo eventualmente registrada em nome do agressor, em casos de violência doméstica.

Para Molon, a medida poderá ajudar a evitar feminicídios, especialmente aqueles cometidos por pessoas próximas à vítima. "Muitas mulheres acabam sendo assassinadas pelos seus companheiros, maridos, ex-maridos, ex-companheiros depois da primeira denúncia de violência doméstica. O que nossa lei faz é garantir que toda vez que alguém agrida outra pessoa, se ela tiver a posse ou porte de arma, a arma será recolhida durante a apuração daquela denúncia". [...] "Isso certamente vai salvar a vida de milhares de mulheres no Brasil", completou.

O Brasil tem a quinta maior taxa de feminicídios do mundo. De acordo com a lei, caberá à autoridade policial verificar se o agressor possui registro de porte ou posse de arma de fogo. Em caso positivo, deverá juntar esta informação aos autos e notificar a instituição responsável pela concessão do registro ou da emissão do porte sobre a ocorrência registrada de violência contra a mulher.

Ao juiz caberá, dentro de 48 horas do recebimento de pedido de medida protetiva, determinar a apreensão da arma.

50 SANCIONADAS Leis que Ampliam Proteção à Vítima de Violência Doméstica. [s.n.: S.1.], 09 out. 2019. Informação postada no site Câmara dos Deputados. Disponível em: <https://www.camara.leg.br/noticias/596798-sancionadas-leis-que-ampliam-protecao-a-vitima-de-violenciadomestica/>. Acesso em: 15 out. 2019. 
O projeto foi aprovado na Câmara no dia 12 de março na forma de texto substitutivo da relatora, deputada Christiane de Souza Yared (PR-PR). No Senado, foi aprovado no dia 7 de agosto.

A outra lei publicada $(13.882 / 19)$ garante prioridade para as mulheres vítimas de violência doméstica matricularem seus filhos em escolas próximas de seu domicílio ou para transferi-los para essas instituições.

O juiz poderá determinar a matrícula independentemente da existência de vaga.

A legislação é originada em projeto da deputada Geovania de Sá (PSDB-SC) (PL 8599/17) e foi aprovada inicialmente em março pela Câmara dos Deputados, na forma do substitutivo da deputada Flávia Arruda (PL-DF). A proposta foi modificada pelo Senado e aprovada novamente pelos deputados no dia 12 de setembro (sob nova numeração - PL 1619/19).

Segundo Geovânia de Sá, a mulher nessa situação está frágil e precisa do apoio do governo. "A mulher, para ser afastada do agressor, muda de residência ou é mandada para um abrigo. $E$ hoje ela tem que aguardar uma vaga na escola. Com a alteração, essa vaga tem que ser garantida a essas crianças."

O direito será garantido mediante a apresentação de documentos que comprovem o registro da ocorrência policial ou do processo de violência doméstica e familiar em curso.

De acordo com a norma, os dados da mulher e os dependentes serão sigilosos. O acesso às informações será reservado ao juiz, ao Ministério Público e aos órgãos competentes do Poder Público. ${ }^{51}$

\subsubsection{Legislação Contra a Violência da Mulher no Brasil}

Embora o Brasil tenha sido um dos últimos países na América Latina a aprovar uma legislação especial introduzindo no cenário normativo nacional uma lei para coibir e prevenir a violência doméstica e familiar contra a mulher, a Lei no 11.340/2006 - popularmente conhecida como Lei Maria da Penha - foi considerada em 2012 pela Organização das Nações Unidas (ONU), a terceira melhor lei do mundo no combate à violência doméstica, perdendo apenas para Espanha e Chile.

Desde 2006, a Lei Maria da Penha vem passando por alterações com o objetivo de aprimorar a eficácia de sua implementação.

Mas, além da Lei no 11.340/06, a violência contra as mulheres também é objeto de muitos outros instrumentos normativos no país. Um exemplo são os Decretos que promulgam as convenções internacionais das quais o governo brasileiro é signatário e que, após

51 SANCIONADAS Leis que Ampliam Proteção à Vítima de Violência Doméstica. [s.n.: S.1.], 09 out. 2019. Informação postada no site Câmara dos Deputados. Disponível em: $<$ https://www.camara.leg.br/noticias/596798-sancionadas-leis-que-ampliam-protecao-a-vitima-de-violenciadomestica/>. Acesso em: 15 out. 2019. 
aprovadas pelo Congresso e sancionadas pela Presidência da República, passam a fazer parte do ordenamento jurídico nacional. ${ }^{52}$

Lei $n^{0} 13.882$, de 8 de outubro de 2019 - Altera a Lei no 11.340, de 7 de agosto de 2006 (Lei Maria da Penha), para garantir a matrícula dos dependentes da mulher vítima de violência doméstica e familiar em instituição de educação básica mais próxima de seu domicílio.

Lei no 13.882, de 8 de outubro de 2019 - Altera a Lei no 11.340, de 7 de agosto de 2006 (Lei Maria da Penha), para garantir a matrícula dos dependentes da mulher vítima de violência doméstica e familiar em instituição de educação básica mais próxima de seu domicílio.

Lei $\mathrm{n}^{\circ}$ 13.880, de 8 de outubro de 2019 - Altera a Lei nำ11.340, de 7 de agosto de 2006 (Lei Maria da Penha), para prever a apreensão de arma de fogo sob posse de agressor em casos de violência doméstica, na forma em que especifica.

Lei no 13.871, de 17 de setembro de 2019 - Altera a Lei no 11.340, de 7 de agosto de 2006 (Lei Maria da Penha), para dispor sobre a responsabilidade do agressor pelo ressarcimento dos custos relacionados aos serviços de saúde prestados pelo Sistema Único de Saúde (SUS) às vítimas de violência doméstica e familiar e aos dispositivos de segurança por elas utilizados.

Lei no 13.836, de 4 de junho de 2019 - Acrescenta dispositivo ao art. 12 da Lei no 11.340, de 7 de agosto de 2006, para tornar obrigatória a informação sobre a condição de pessoa com deficiência da mulher vítima de agressão doméstica ou familiar.

Lei no 13.827 de 13 de maio de 2019 - Altera a Lei no 11.340, de 7 de agosto de 2006 (Lei Maria da Penha), para autorizar, nas hipóteses que especifica, a aplicação de medida protetiva de urgência, pela autoridade judicial ou policial, à mulher em situação de violência doméstica e familiar, ou a seus dependentes, e para determinar o registro da medida protetiva de urgência em banco de dados mantido pelo Conselho Nacional de Justiça.

\footnotetext{
52 LEGISLAÇÃO Sobre Violência Contra as Mulheres no Brasil. [S.n.t]. Informação postada no site Compromisso e Atitude Lei Maria da Penha. Disponível em: <http://www.compromissoeatitude.org.br/legislacao-sobre-violencia-contra-as-mulheres-no-brasil/>. Acesso em: 03 nov. 2019.
} 
Lei $\mathrm{n}^{0}$ 13.772, de 19/12/2018 - Altera a Lei ํㅜ 11.340, de 7 de agosto de 2006 (Lei Maria da Penha), e o Decreto-Lei no 2.848, de 7 de dezembro de 1940 (Código Penal), para reconhecer que a violação da intimidade da mulher configura violência doméstica e familiar e para criminalizar o registro não autorizado de conteúdo com cena de nudez ou ato sexual ou libidinoso de caráter íntimo e privado.

Lei $\mathrm{n}^{\circ}$ 13.772, de 19/12/2018 - Altera a Lei ํㅜ 11.340, de 7 de agosto de 2006 (Lei Maria da Penha), e o Decreto-Lei nº 2.848, de 7 de dezembro de 1940 (Código Penal), para reconhecer que a violação da intimidade da mulher configura violência doméstica e familiar e para criminalizar o registro não autorizado de conteúdo com cena de nudez ou ato sexual ou libidinoso de caráter íntimo e privado.

Lei no 13.718, de 24/09/2018 - Altera o Decreto-Lei no 2.848, de 7 de dezembro de 1940 (Código Penal), para tipificar os crimes de importunação sexual e de divulgação de cena de estupro, tornar pública incondicionada a natureza da ação penal dos crimes contra a liberdade sexual e dos crimes sexuais contra vulnerável, estabelecer causas de aumento de pena para esses crimes e definir como causas de aumento de pena o estupro coletivo e o estupro corretivo.

Lei $n^{\circ}$ 13.642, de 03/04/2018 - Altera a Lei $n^{0} 10.446$, de 8 de maio de 2002, para acrescentar atribuição à Polícia Federal no que concerne à investigação de crimes praticados por meio da rede mundial de computadores que difundam conteúdo misógino, definidos como aqueles que propagam o ódio ou a aversão às mulheresLei no 13.641, de 03/04/2018 - Altera a Lei $n^{\circ}$ 11.340, de 7 de agosto de 2006 (Lei Maria da Penha), para tipificar o crime de descumprimento de medidas protetivas de urgência.

Lei $\mathrm{n}^{0}$ 13.505, de 08/11/2017 - Acrescenta dispositivos à Lei no 11.340, de 7 de agosto de 2006 (Lei Maria da Penha), para dispor sobre o direito da mulher em situação de violência doméstica e familiar de ter atendimento policial e pericial especializado, ininterrupto e prestado, preferencialmente, por servidores do sexo feminino.

Lei nำ13.104, de 09/03/2015 - Altera o art. 121 do Código Penal, para prever o feminicídio como circunstância qualificadora do crime de homicídio, e o art. 10 da Lei de Crimes Hediondos, para incluir o feminicídio no rol dos crimes hediondos. 
Lei no 11.340, de 07/08/2006 - Lei Maria da Penha, cria mecanismos para coibir a violência doméstica e familiar contra a mulher.

Lei no 10.778, de 24/11/2003 - Lei da Notificação Compulsória dos casos de violência contra a mulher que forem atendidos em serviço de saúde pública ou privada.

Lei no 12.015 , de 07/08/2009 - Dispõe sobre os crimes contra a dignidade sexual.

Lei no 12.845, de 01/08/2013 - Dispõe sobre o atendimento obrigatório e integral de pessoas em situação de violência sexual

Lei 13.285/2016, de 10/05/2016 - Dispõe sobre a preferência de julgamento dos processos concernentes a crimes hediondos.

Resolução no 1, de 16/01/2014 - Dispõe sobre a criação da Comissão Permanente Mista de Combate à Violência contra a Mulher do Congresso Nacional.

Lei Estadual n 14.478, de 23/01/2014 - Dispõe sobre o monitoramento eletrônico de agressor no âmbito do Estado do Rio Grande do Sul.

Código Penal Brasileiro - Decreto-Lei no 2.848, de 07/12/1940.

Constituição Federal, parág. 8\%/art. 226 - Dispõe que o Estado criará mecanismos para coibir a violência no âmbito das relações familiares.

Lei Orgânica da Defensoria Pública (Lei Complementar nº 80, de 12/01/1994)

Decreto no 9.586, de 27 de novembro de 2018 - Institui o Sistema Nacional de Políticas para as Mulheres e o Plano Nacional de Combate à Violência Doméstica.

Decreto no 7.958, de 13/03/2013 - Estabelece diretrizes para o atendimento às vítimas de violência sexual pelos profissionais de segurança pública e da rede de atendimento do Sistema Único de Saúde.

Decreto n 7.393 , de 15/12/2010 - Dispõe sobre o funcionamento do Ligue 180 - Central de Atendimento à Mulher.

Decreto no 1.973, de 01/08/1996, que promulgou a Convenção Interamericana para Prevenir, Punir e Erradicar a Violência contra a Mulher, Belém do Pará, 09/06/1994). 
Decreto no 89.460, de 20/03/1984, que promulgou a Convenção sobre a Eliminação de todas as formas de Discriminação Contra a Mulher/CEDAW, 1979)

Decreto $\mathrm{n}^{\circ}$ 5.017, de 12/03/2004, que promulgou o Protocolo de Palermo (Protocolo Adicional à Convenção das Nações Unidas contra o Crime Organizado Transnacional Relativo à Prevenção.

Repressão e Punição do Tráfico de Pessoas, em Especial Mulheres e Crianças.

Decreto n 678 , de 06/11/1992, promulgou o Pacto de São José da Costa Rica (Convenção Americana sobre Direitos Humanos, de 22/11/1969).

\subsubsection{Precedentes Originários da Súmula 588 do STJ}

Súmula 588 do STJ - A prática de crime ou contravenção penal contra a mulher com violência ou grave ameaça no ambiente doméstico impossibilita a substituição da pena privativa de liberdade por restritiva de direitos. (Súmula 588, TERCEIRA SEÇÃO, julgado em 13/09/2017, DJe 18/09/2017)

"[...] VIAS DE FATO RECONHECIDAS PELO ACÓRDÃO RECORRIDO. VIOLAÇÃO DO ART. 44, I, DO CP. OCORRÊNCIA. SUBSTITUIÇÃO DA PENA. IMPOSSIBILIDADE. CRIME COMETIDO COM VIOLÊNCIA À PESSOA. [...] 2. A jurisprudência pacífica deste Superior Tribunal de Justiça tem se direcionado pela impossibilidade de substituição da pena privativa de liberdade por restritiva de direitos em hipótese de violência doméstica (art. 44, I, do CP). 3. No caso, o agravante praticou vias de fato contra a sua ex-esposa, fato que se insere na proibição legal de substituição, nos termos do art. 44, I, do Código Penal, o que impõe a reforma do acórdão local. [...]" (AgRg no REsp $1534703 \mathrm{MS}$, Rel. Ministro RIBEIRO DANTAS, QUINTA TURMA, julgado em 20/09/2016, DJe 28/09/2016) Precedentes originários da Súmula 588 do STJ

"[...] VIOLÊNCIA DOMÉSTICA. SUBSTITUIÇÃO DA PENA PRIVATIVA DE LIBERDADE POR RESTRITIVAS DE DIREITOS. IMPOSSIBILIDADE. Não há falar em conversão da pena privativa de liberdade para restritiva de direitos quando o delito envolve violência ou grave ameaça à pessoa, ex vi do art. 44, I, do Código Penal. [...]" (AgRg no AREsp 710998 MS, Rel. Ministro FELIZ FISHCER, QUINTA TURMA, julgado em 20/10/2015, DJe 29/10/2015)

"[...] 1. Hipótese quem que o recorrente foi condenado por ofender a integridade corporal de sua companheira, agredindo-a fisicamente, causando-lhe lesões corporais de natureza leve, bem como por ameaçá-la de causar-lhe mal injusto e grave. 2. O Tribunal a quo, ratificando o édito condenatório, vedou a substituição da pena privativa de liberdade imposta em desfavor do agravante, a despeito desta ter sido fixada em patamar inferior a 4 (quatro) anos, em razão 
do delito ter sido praticado com emprego de violência e grave ameaça, o que por si só, obsta a concessão do aludido benefício, nos termos do art. 44, I, do Código Penal. [...]" (AgRg no AREsp 733395 MS, Rel. Ministro JORGE MUSSI, QUINTA TURMA, julgado em 15/10/2015, DJe 21/10/2015)

"[...] CONTRAVENÇÃO PENAL. VIAS DE FATO. VIOLÊNCIA DOMÉSTICA. PRETENSÃO PELA CONVERSÃO DA PENA PRIVATIVA DE LIBERDADE POR RESTRITIVA DE DIREITOS. IMPOSSIBILIDADE. [...] 1. A substituição da pena privativa de liberdade por restritiva de direitos pressupõe que o crime não tenha sido cometido com violência ou grave ameaça, o que não ocorreu no caso em tela, pois consta dos autos ter a vítima sofrida vários tipos de agressões, como socos e aperto no pescoço. Essa circunstância, por si só, inviabiliza a substituição da pena. [...]" (AgRg no AREsp 788967 MS, Rel. Ministro SEBASTIÃO REIS JÚNIOR, SEXTA TURMA, julgado em 17/12/2015, DJe 03/02/2016) ) $^{53}$

\subsection{FEMINICÍDIO - LEI 13.104/2006}

Feminicídio, termo utilizado para fazer referência a morte de mulheres, qualificadora agregada ao Código Penal para alterar o rol do homicídio qualificado, ou seja, morte em razão do gênero, morte por violência de gênero através da execução do ato mais grave de violência contra mulher.

Francisco Porfírio explica o que é o feminicídio:

O feminicídio é o homicídio praticado contra a mulher em decorrência do fato de ela ser mulher (misoginia e menosprezo pela condição feminina ou discriminação de gênero, fatores que também podem envolver violência sexual) ou em decorrência de violência doméstica. A lei 13.104/15, mais conhecida como Lei do Feminicídio, alterou o Código Penal brasileiro, incluindo como qualificador do crime de homicídio o feminicídio. ${ }^{54}$

53 SÚMULA 588 do STJ Anotada (Violência Doméstica). [s.n.: S. 1.], 15 abr. 2019. Informação postada no site Canal Ciências Criminais. Disponível em: <https://canalcienciascriminais.com.br/sumula-588-do-stjanotada/>. Acesso em: 03 nov. 2019.

54 PORFÍRIO, Francisco. Feminicídio. [S.n.t.]. Informação postada no site Brasil Escola. Disponível em: <https://brasilescola.uol.com.br/sociologia/feminicidio.htm>. Acesso em: 15 out. 2019. 
A Lei $13.104 / 2015^{55}$ conhecida como Lei do Feminicídio alterou disposição do artigo 121, § 2ำ VI do Código Penal, para determinar agravante para o crime de homicídio com base no gênero biológico da vítima.

O feminicídio é o ápice da violação do direito fundamental à vida, praticado contra uma mulher, que em regra figura na história como vítima de violências por pertencer ao "sexo frágil".

Francisco Porfírio discorre sobre os tipos relacionados ao feminicídio:

Tipos de feminicídio. A Lei do Feminicídio não enquadra, indiscriminadamente, qualquer assassinato de mulheres como um ato de feminicídio. O desconhecimento do conteúdo da lei levou diversos setores, principalmente os mais conservadores, a questionarem a necessidade de sua implementação. Devemos ter em mente que a lei somente aplica-se nos casos descritos a seguir: Violência doméstica ou familiar: quando o crime resulta da violência doméstica ou é praticado junto a ela, ou seja, quando o homicida é um familiar da vítima ou já manteve algum tipo de laço afetivo com ela. Esse tipo de feminicídio é o mais comum no Brasil, ao contrário de outros países da América Latina, em que a violência contra a mulher é praticada, comumente, por desconhecidos, geralmente com a presença de violência sexual. Menosprezo ou discriminação contra a condição da mulher: quando o crime resulta da discriminação de gênero, manifestada pela misoginia e pela objetificação da mulher. A violência contra a mulher, muitas vezes, acontece na própria casa da vítima e é praticada por um familiar. Quando o assassinato de uma mulher é decorrente, por exemplo, de latrocínio (roubo seguido de morte) ou de uma briga simples entre desconhecidos ou é praticado por outra mulher, não há a configuração de feminicídio. O feminicídio somente qualificará um homicídio nos casos descritos nos tópicos acima. ${ }^{56}$

A Lei $13.104 / 2015^{57}$ entrou em vigor em março de 2015, prevendo ainda causas de aumento de pena para o crime contra vida, consumado. Esse tipo penal

\footnotetext{
${ }^{55}$ BRASIL. Lei n. 13.104, de 9 de março de 2015. Altera o art. 121 do Decreto-Lei no 2.848, de 7 de dezembro de 1940 - Código Penal, para prever o feminicídio como circunstância qualificadora do crime de homicídio, e o art. 1o da Lei no 8.072, de 25 de julho de 1990, para incluir o feminicídio no rol dos crimes hediondos. Disponível em: <http://www.planalto.gov.br/ccivil_03/_Ato2015-2018/2015/Lei/L13104.htm\#art1>. Acesso em: 15 out. 2019.

${ }^{56}$ PORFÍRIO, Francisco. Feminicídio. [S.n.t.]. Informação postada no site Brasil Escola. Disponível em: <https://brasilescola.uol.com.br/sociologia/feminicidio.htm〉. Acesso em: 15 out. 2019.

${ }^{57}$ BRASIL. Lei n. 13.104, de 9 de março de 2015. Altera o art. 121 do Decreto-Lei no 2.848, de 7 de dezembro de 1940 - Código Penal, para prever o feminicídio como circunstância qualificadora do crime de homicídio, e o art. 1o da Lei no 8.072, de 25 de julho de 1990, para incluir o feminicídio no rol dos crimes hediondos. Disponível em: <http://www.planalto.gov.br/ccivil_03/_Ato2015-2018/2015/Lei/L13104.htm\#art1>. Acesso em: 10 out. 2019.
} 
surgiu do clamor social por maior eficácia na punição dos agressores e assassinos de mulheres, dispositivo pelo qual se tem a consolidação do tratamento desigual aos desiguais, já que institui previsão especifica por conta de gênero e característica da vítima.

A alteração traz a seguinte disciplina:

VI - contra a mulher por razões da condição de sexo feminino: (Incluído pela Lei no 13.104, de 2015)

VII - contra autoridade ou agente descrito nos arts. 142 e 144 da Constituição Federal, integrantes do sistema prisional e da Força Nacional de Segurança Pública, no exercício da função ou em decorrência dela, ou contra seu cônjuge, companheiro ou parente consanguíneo até terceiro grau, em razão dessa condição: (Incluído pela Lei $n=13.142$, de 2015)

Pena - reclusão, de doze a trinta anos.

$\S 2^{\circ}$-A Considera-se que há razões de condição de sexo feminino quando o crime envolve: (Incluído pela Lei no 13.104, de 2015)

I - violência doméstica e familiar; (Incluído pela Lei nº 13.104, de 2015)

II - menosprezo ou discriminação à condição de mulher. ${ }^{58}$

É incontestável que a tipificação do feminicídio tem como basilar a ocorrência da violência de gênero, em razão de que a conduta se caracteriza por menosprezo ao sexo feminino.

Guilherme de Souza Nucci explica que se trata de uma qualificadora objetiva:

Trata-se de uma qualificadora objetiva, pois se liga ao gênero da vítima: ser mulher. Não aquiescemos à ideia de ser uma qualificadora subjetiva (como o motivo torpe ou fútil) somente porque se inseriu a expressão "por razões de condição de sexo feminino". Não é essa a motivação do homicídio. O agente não mata a mulher porque ela é mulher, mas o faz por ódio, raiva, ciúme, disputa familiar, prazer, sadismo, enfim, motivos variados, que podem ser torpes ou fúteis; podem, inclusive, ser moralmente relevantes. Sendo objetiva, pode conviver com outras circunstâncias de cunho puramente subjetivo. Exemplificando, pode-se matar a mulher, no ambiente doméstico, por motivo fútil (em virtude de uma banal

\footnotetext{
${ }^{58}$ BRASIL. Lei n. 13.104, de 9 de março de 2015. Altera o art. 121 do Decreto-Lei no 2.848 , de 7 de dezembro de 1940 - Código Penal, para prever o feminicídio como circunstância qualificadora do crime de homicídio, e o art. 1o da Lei no 8.072, de 25 de julho de 1990, para incluir o feminicídio no rol dos crimes hediondos. Disponível em: <http://www.planalto.gov.br/ccivil_03/_Ato2015-2018/2015/Lei/L13104.htm\#art1>. Acesso em: 10 out. 2019.
} 
discussão entre marido e esposa), incidindo duas qualificadoras: ser mulher e haver motivo fútil. .59

Buscando compreender que o feminicídio é conduta praticada em razão do gênero, faz-se necessário delinear se há possibilidade de que o transexual seja vítima desse crime, em breves linhas define-se a transexualidade nas palavras de Rodrigo Chandoha da Cruz:

São pessoas que sofrem de neurodiscordância de gênero, nome que se originou em pesquisas norte-americanas, onde foi constatado em cadáveres de transexuais do sexo masculino, que a hipófise cerebral (que é a parte do cérebro que responde aos estímulos sexuais) possui estrias mais estreitas diferentes aos dos homens comuns, sendo idênticas a de uma mulher biológica. Baseando-se em tal pesquisa é que hoje alguns profissionais entendem 0 transexualismo como hermafroditismo hipofásico. Fato que faz com que a idéia de que um transexual seria uma pessoa que desejaria trocar ou mudar de sexo, seja ultrapassada e ultrajante, onde o transexual não deve ser colocado neste patamar discriminatório de mutantes, quando na verdade, a procura dos transexuais nada mais é do que a simples adaptação física, para exercer suas vidas emocionais, sociais, espíritas e sexuais, o que infelizmente não são alcançadas pela maioria, e numa minoria são conquistadas aos poucos e as duras penas. ${ }^{60}$

Ainda, segundo expõe Cristiano Chaves de Farias e Nelson Rosenvald:

O transexual não pode ser confundido com o homossexual, bissexual, intersexual (também conhecido como hermafrodita) ou mesmo com o travesti. O transexual é aquele que sofre uma dicotomia físico-psíquica, possuindo um sexo físico, distinto de sua conformação sexual psicológica. Nesse quadro, a cirurgia de mudança de sexo pode se apresentar como um modo necessário para a conformação do seu estado físico e psíquico"61

Diante de tais conceitos, ousa-se extrair que o transexual, não confundível com o homossexual ou travesti, possui em sua psique uma confusão de identidade

\footnotetext{
${ }^{59}$ NUCCI, Guilherme de Souza. Código penal comentado. 17. ed. rev., atual. e ampl. Rio de Janeiro: Forense, 2017, p. 455.

${ }^{60}$ CRUZ, Rodrigo Chandoha. O Reconhecimento do Transexual pelo Ordenamento Jurídico Brasileiro. 2009. 105f. Trabalho de Conclusão de Curso (Graduação) - Universidade do Vale do talaí. p. 10.

${ }^{61}$ FARIAS, Cristiano Chaves de e ROSENVALD, Nelson. Curso de Direito Civil: parte geral e LINDB, v. 1, Editora Atlas: São Paulo, 2015. p. 183.
} 
de gênero, rejeitando sua característica físico-sexual para prover-se perante a sociedade como se enxerga psicologicamente, ou seja, com os atributos do sexo oposto ao de seu nascimento. A adaptação do transexual é advinda com a cirurgia de mudança de sexo, conformando-se, por corolário, sua característica física com a psicológica.

Como ao Direito nada se constrói sobre único pilar, duas correntes dividirão bons argumentos sobre a possibilidade, ou não, do transexual figurar como vítima do crime de feminicídio.

Conforme publicado por Wanderley Elenilton Gonçalves Santos:

A primeira posição, de cunho conservadora, menciona, categoricamente, que o transexual não é mulher, apesar de transmudar fisicamente seu órgão genital, razão pela qual, não poderia estar abarcado pela proteção especial da Lei no 13.104/2015. De acordo com Victor Eduardo Rios Gonçalves, "somente mulheres podem ser sujeito passivo de feminicídio."

Sob o mesmo prisma, para Francisco Dirceu Barros, "identifica-se a mulher em sua concepção genética ou cromossômica. Neste caso, como a neocolpovulvoplastia [cirurgia de transgenitalização] altera a estética, mas não a concepção genética, não será possível a aplicação da qualificadora do feminicídio".

A segunda corrente, com tendência mais moderna, defende que se o transexual tiver feito a cirurgia de mudança de sexo de forma definitiva e a retificação de seu registro civil, deve ter o tratamento dispensado de acordo com a sua nova característica física, vez que a psicológica já o colocava nessa posição.

Verifica-se que tal posicionamento combina dois critérios: a) o biopsicológico, consistente na realização da mudança do sexo de origem para correlação ao sexo psicológico e, b) o jurídico, traduzindo-se como a alteração do gênero nos assentamentos civis.

Nessa toada, Rogério Sanches Cunha, simpático a esta contemporânea corrente, diz que "a mulher de que trata a qualificadora é aquela assim reconhecida juridicamente. No caso de transexual que formalmente obtém o direito de ser identificado civilmente como mulher, não há como negar a incidência da lei penal porque, para todos os demais efeitos, esta pessoa será considerada mulher".

Seguindo essa mesma linha de raciocínio, Celso Delmanto, afirma que o transexual que mantém o psiquismo voltado para o gênero feminino e que tenha realizado tanto a cirurgia de mudança de órgãos genitais, quanto a alteração em seu registro civil para fazer constar mulher, poderá ser abrangido pela proteção especial do feminicídio.

Rogério Greco, sintetizando a temática, explica que "aquele que for portador de um registro oficial (certidão de nascimento, documento de identidade) onde figure, expressamente, o seu sexo feminino, poderá ser considerado sujeito passivo do feminicídio". 
Vê-se, portanto que a corrente moderna, vem ganhando força com argumentos cada vez mais convincentes e harmônicos ao cenário social atual. Ignorar a galopante evolução das pessoas e das ciências, seria o mesmo que engessar o Direito, impedindo 0 progresso da hermenêutica jurídica à realidade contemporânea.

Em que pese os renomados juristas defensores da posição ortodoxa, em rechaçar a possibilidade da pessoa transexual ser protegida pela figura do feminicídio, fato é que, sob o prisma teleológico, quis a Lei $13.104 / 2015$ proteger o polo mais fraco da relação afetiva ou social, seja ela biologicamente mulher ou juridicamente mulher, razão pela qual, filiamo-nos a corrente moderna.

Como Prevê o art. 121, § 2.․․ VI, do Código Penal a figura típica do denominado feminicídio, espécie nova de qualificadora do crime de homicídio acrescentada pela Lei 13.104/2015, que tem a seguinte redação:

Pela literalidade da lei, apenas poderia ser sujeito passivo de tal infração penal a mulher, em seu sentido genético, ou seja, na hipótese de um travesti ou transexual, mesmo que este último tivesse alterado, por meio de cirurgia, seu sexo, continuariam a ser, em seus genes, homens, o que afastaria a aplicação da Lei Maria da Penha, sob pena de se aplicar, em sede de direito penal, analogia in malam partem. ${ }^{62}$

Não obstante o aparente acerto desse raciocínio linear, o Supremo reconheceu, ao julgar a Ação Direta de Inconstitucionalidade (ADI) 427563, conferindo interpretação conforme ao art. 58 da Lei 6.015/1973 (Lei dos Registros Públicos), que é possível a alteração de prenome e gênero no registro civil, mediante averbação no registro original, independentemente de cirurgia de transgenitalização e sem a necessidade de autorização judicial. A desnecessidade de autorização judicial e o risco, pela ausência de controle judicial na mudança de prenome e gênero realizada diretamente em cartório, pela possibilidade de sua prática fraudulenta ou abusiva, poderiam ser coarctadas, segundo o Min. Celso de Mello, do STF, por meio da fiscalização exercida pelo oficial do registro civil das pessoas naturais, que pode instaurar o processo administrativo de dúvida. Pensamos, todavia, que o melhor posicionamento quanto à questão foi a vencida, sustentada pelos Ministros Alexandre de Moraes, Ricardo Lewandowski e Gilmar Mendes, os quais condicionaram a alteração no registro civil à ordem judicial e à

\footnotetext{
${ }^{62}$ SANTOS, Wanderley Elenilton Gonçalves. Transexual pode ser vítima de feminicídio?. [S,n,t.]. Informação postada no site Jusbrasil. Disponível <https://delegadowanderley.jusbrasil.com.br/artigos/378934999/transexual-pode-ser-vitima-de-feminicidio〉. Acesso em: 10 out. 2019.

${ }^{63}$ STF Reconhece a Transgêneros Possibilidade de Alteração de Registro Civil sem Mudança de Sexo. [s.n.: S.1.], 01 mar. 2018. Informação postada no site do Supremo Tribunal Federal (STF). Disponível em: < http://www.stf.jus.br/portal/cms/verNoticiaDetalhe.asp?idConteudo=371085>. Acesso em: 10 out. 2019.
} 
averbação no registro civil de nascimento, resguardado sigilo no tocante à modificação. Tal procedimento judicial, a nosso ver, em nada comprometeria o exercício, pelos transgêneros, de seu direito à alteração de prenome e gênero, ao mesmo tempo que - pelo controle judicial e com a indispensável participação no processo do Ministério Público - se resguardaria "aos imperativos de veracidade e de publicidade dos registros públicos", como salientado pelo Min. Gilmar Mendes, em seu voto-vogal.

Percebe-se que, nessa condição de alteração do registro civil de homem para mulher, o homem passa a ser considerado, no mundo jurídico, como uma mulher, de modo que, in casu, se torna juridicamente possível que o transexual seja tido como sujeito passivo de quaisquer das condutas descritas na Lei Maria da Penha em estudo, bem como vítima do feminicídio previsto no art. $121, \S 2 .$. , VI, do CP.

A conclusão exposta supra, no sentido de conferir ao transexual o direito de ser considerado, juridicamente, como mulher, pelo que se depreende do teor da decisão referente à ADI 4275, abarcaria, inclusive, os travestis, uma vez que a autodeterminação de gênero estaria no campo psicológico, devendo ser reconhecida no âmbito social e jurídico. Desse modo, em tese, os travestis, além dos transexuais, poderiam ser contemplados pelas medidas protetivas previstas na Lei Maria da Penha, bem como ser vítimas do delito de feminicídio.[2] Por sua vez, os homossexuais masculinos que não tenham qualquer pretensão de mudar de sexo, nem se comportam como se fossem do sexo feminino, não podem ser considerados, obviamente, como mulheres, não se aplicando a eles quaisquer dos institutos da Lei Maria da Penha.

Por fim, saliente-se que a possibilidade ou não de constar a existência da qualificadora do feminicídio, no caso de ofendido transexual ou travesti, deverá ser, necessariamente, dirimida, quando da prolação de pronúncia; reconhecida a qualificadora no contexto ora em estudo, não há como se eximir o juiz presidente de indagá-la aos jurados.

Em outra decisão do Supremo, o Min. Luiz Barroso concedeu habeas corpus (HC 152491/SP) a fim de que travestis, presos em uma cela com 31 homens, fossem removidos para estabelecimento prisional, compatível com sua orientação sexual (presídio feminino). 
Ainda que a temática seja relativamente nova, ao operador do direito é de rigor enfrenta-la. O mundo moderno urge por soluções à altura de seu progresso. Ainda que não seja com ele anuente, deve, ao menos, ser compatível com o que se espera de uma ciência evolutiva. O Direito já respondeu e se adaptou com maestria à era ambiental, à era coletiva, à era digital e, hodiernamente deve encarar com ética e responsabilidade o desafio de adequação dos transexuais à sua realidade, a fim de que não remanesça sem identidade social, seja no âmbito do direito privado e, principalmente, diante do direito público, obrigação maior do Estado e objeto do presente texto, o qual teve por objetivo estimular a discussão acerca do feminicídio e a possibilidade da pessoa transexual figurar como vítima desse crime hediondo.

\subsection{A VIOLÊNCIA E O FEMINICÍDIO NO BRASIL}

A violência contra mulher está longe de ser uma realidade erradicada, ao contrário, sobram leis e faltam medidas efetivas que possam mudar esse triste e infeliz cenário: em que pessoas tem sua integridade e seus direitos violados apenas por pertencerem a um gênero "desigual".

Mesmo com o advento de leis que regulamentam questões contra a violência que tem a mulher como vítima, todos os dias é possível encontrar sendo noticiados casos em que a mulher era vítima de violência doméstica, denunciou e por fim acabou morta.

O relato abaixo é de uma situação em que a vítima inclusive tinha medida protetiva:

Uma mulher foi morta com sete tiros, no Bairro Santa Mônica, na região de Venda Nova, em Belo Horizonte, nessa quarta-feira. O crime aconteceu dentro de um salão de beleza. De acordo com testemunhas, a vítima teria pedido proteção à polícia por causa de ameaças de morte, feitas pelo ex-marido, identificado como Fábio Willian, de 30 anos, borracheiro, autor dos disparos. ${ }^{64}$

\footnotetext{
${ }^{64}$ CABELEIREIRA é morta pelo ex-marido com sete tiros dentro de salão de beleza em Minas Gerais. [s.n.], Minas Gerais, 21 jan. 2010. Informação postada no site O Globo. Disponível em: <http://oglobo.globo.com/brasil/cabeleireira-morta-pelo-ex-marido-com-sete-tiros-dentro-de-salao-de-belezaem-minas-gerais-3065361>. Acesso em: 20 out. 2019.
} 
Em outra situação a vítima carregava suas medidas protetivas no próprio bolso, mesmo assim temia por sua vida:

\begin{abstract}
Antes de ser assassinada a facadas pelo ex-companheiro, Jacqueline Pereira dos Santos, 37 anos, mandou mensagem por áudio a uma colega mostrando que temia pela própria vida. $\mathrm{O}$ motoboy Maciel Luiz Coutinho da Silva, 38, matou a ex-mulher em Santa Maria, dentro da casa dela, na tarde dessa segunda-feira (6/5). A mensagem, enviada por um aplicativo de celular, foi encaminhada momentos antes de a vítima sair do trabalho e ir para casa. Ao chegar na residência, ela foi atingida pelas facadas. No bolso traseiro da calça dela, estavam as medidas protetivas contra o agressor. Ela chegou a registrar ao menos duas ocorrências de violações à Lei Maria da Penha contra o ex-marido. A Justiça concedeu duas medidas protetivas em favor da vítima. Segundo informações da Polícia Civil, ele não aceitava o término do relacionamento. ${ }^{65}$
\end{abstract}

As vítimas de feminicídio são as mesmas que sofrem anos com a violência doméstica, muitas delas cansadas da situação noticiam as autoridades e pedem medidas protetivas, mas ainda assim, seus agressores continuam impunes para cometer $\mathrm{o}$ ato mais grave.

Essa situação inclusive é pauta de projeto de lei votado e aprovado na Câmara dos Deputados que prevê o aumento da pena até $1 / 3$ nos casos de feminicídio em que o crime tenha ocorrido em descumprimento a medidas protetivas impostas pela Lei Maria da Penha. 66

A situação encontrada nos índices de violência contra mulher reporta a conclusão de que as medidas legais, na prática, ainda são ineficazes, como por exemplo, na ocorrência abaixo transcrita houveram oito denúncias por parte dos vizinhos à autoridade policial e, na falta de ação e efetivo dessa, a mulher foi morta pelo próprio marido:

\footnotetext{
65 PERES, Sarah. Vítima de feminicídio carregava medidas protetivas no bolso quando morreu. Informação postada no site Correio Braziliense, em 07 de maio de 2019. Disponível em: <https://www.correiobraziliense.com.br/app/noticia/cidades/2019/05/07/interna_cidadesdf,753613/vitima-defeminicidio-carregava-medidas-protetivas-bolso-quando-morreu.shtml>. Acesso em: 25 out. 2019.

${ }^{66}$ CÂMARA Aprova Aumento de Pena Para Feminicídio. [s.n.: S.l.], 28 nov. 2018. Informação postada no site Câmara dos Deputados, no hiperlink Direito e Justiça. Disponível em: <https://www.camara.leg.br/noticias/548778-camara-aprova-aumento-de-pena-para-feminicidio/>. Acesso em: 20 out. 2019.
} 
Vizinhos chamaram polícia oito vezes antes de mulher ser morta por marido no PR. [...] Na madrugada de 14 de janeiro, Daniela Eduarda Alves foi morta a facadas pelo marido Emerson Bezerra, 34 anos, em Fazenda Rio Grande, município da Região Metropolitana de Curitiba. Gravações telefônicas revelam que vizinhos acionaram a Polícia Militar (PM) diversas vezes para denunciar as agressões e os pedidos de socorro da vítima. Segundo a investigação, as agressões teriam começado por volta das 23 horas mas a viatura da PM chegou ao local somente às $2 \mathrm{~h} 20$. A vítima já estava morta há 20 minutos. Emerson foi preso horas depois. [...] As ligações para a Polícia Militar continuam. Os vizinhos relatam que vão dormir com os gritos de socorro. "Já pedimos umas três vezes, o cara está matando a mulher aqui e ninguém veio até agora", diz uma moradora. "Tem que aguardar, senhora. A ocorrência está aberta", responde o atendente da Central de Operações Policiais Militares (Copom). Os carros estariam em atendimento em outras ocorrências na região. ${ }^{67}$

As medidas protetivas não representam mecanismos eficazes para conter e combater o agressor, há casos em que a situação instaurada recomenda a imposição de meios mais gravosos contra esse a fim de que se possa evitar que a ocorrência tenha o feminicídio como resultado.

O Brasil ocupa 5 a posição no ranking de pais com maiores números de morte de mulheres, conforme aponta o Alto Comissariado das Nações Unidas para os Direitos Humanos (ACNUDH), o país perde apenas para países como El Salvador, Colômbia, Guatemala e Rússia em casos de assassinato de mulheres, com números 48 vezes maiores que o Reino Unido, por exemplo. ${ }^{68}$

Noticiários pelo país a fora dão conta de que além dos números alarmantes da violência da doméstica, o feminicídio tem crescido de forma exorbitante, tendo como local principal o ambiente doméstico:

Casos de feminicídio tiveram um aumento de $76 \%$ só no primeiro trimestre de 2019, em São Paulo. Foram 37 casos os três primeiros meses deste ano. O levantamento foi feito pelo G1 em comparação com o mesmo período de 2018. O relatório mostra também que oito em cada dez casos aconteceram dentro da casa da vítima, e 26 dos

\footnotetext{
${ }^{67}$ GARCEL, Fernando. Vizinhos chamaram polícia oito vezes antes de mulher ser morta por marido no PR. [s.n.], Curitiba/PR, 15 mar. 2019. Informação postada no site Paraná Portal UOL, no hiperlink cidades. Disponível em: <https://paranaportal.uol.com.br/cidades/vizinhos-chamaram-policia-oito-vezes-antes-demulher-ser-morta-por-marido-no-pr/>. Acesso em: 25 out. 2019.

${ }^{68}$ CUNHA, Carolina. Feminicídio - Brasil é o $5^{\circ}$ país em morte violentas de mulheres no mundo. [S.n.t.]. Informação postada no site Vestibular Uol. Disponível em: <https://vestibular.uol.com.br/resumo-dasdisciplinas/atualidades/feminicidio-brasil-e-o-5-pais-em-morte-violentas-de-mulheres-no-mundo.htm?>.

Acesso em: 25 out. 2019.
} 
37 feminicídios foram cometidos por um conhecido da vítima. No primeiro semestre de 2018, vítimas de feminicídio representavam $17,5 \%$ do total de casos, em 2019 , subiu para $38 \% .{ }^{69}$

Após a promulgação da Lei do feminicídio os casos de violência contra a mulher dispararam, em muitos a vítima já havia denunciado o agressor que continuou impune.

As mortes em razão da violência de gênero retratam uma situação global, não é algo restrito ao Brasil, o que retrata a continuidade de culturas machistas que colocam a mulher em situação de desigualdade e inferioridade, que a estabelece como objeto e propriedade dos homens.

\subsubsection{Pena Maior para Crime de Feminicídio foi Aprovada em 2018}

Aumento da pena de feminicídio e acompanhamento psicossocial do agressor estão entre as medidas aprovadas

Em 2018, foram aprovadas propostas consideradas prioritárias pela bancada feminina e pela Secretaria da Mulher e Procuradoria da Mulher da Câmara. Mais uma vez, a Casa participou da campanha mundial de 16 Dias de Ativismo pelo Fim da Violência contra as Mulheres e promoveu sessões de votação dedicadas ao tema.

O Plenário aprovou um novo caso de aumento de pena para o crime de feminicídio. Se o crime for praticado em descumprimento de medida protetiva de urgência prevista na Lei Maria da Penha (Lei 11.340/06), o aumento da pena será de $1 / 3$ à metade. A proposta original (PL 3030/15), do deputado Lincoln Portela (PR-MG), já foi sancionada e entrou em vigor em dezembro.

O texto enviado à sanção é o mesmo aprovado no Plenário da Câmara em março de 2016. Além desse novo agravante relacionado ao descumprimento de medidas protetivas, o texto inclui outros como o crime praticado contra pessoa portadora de doenças degenerativas que acarretem condição limitante ou de vulnerabilidade física ou

69 ACAYABA, Cinthia. [s.n.: S.1.], 29 abr. 2019. Informação postada no site Globo G1. Disponível em: <https:/g1.globo.com/sp/sao-paulo/noticia/2019/04/29/casos-de-feminicidio-aumentam-76percent-no-1otrimestre-de-2019-em-sp-numero-de-mulheres-vitimas-de-homicidio-cai.ghtml>. Acesso em: 15 out. 2019. 
mental; e se o crime for cometido na presença física ou virtual de descendente ou de ascendente da vítima.

O Código Penal estipula a pena de reclusão de 12 a 30 anos para o homicídio contra a mulher por razões da condição de sexo feminino (feminicídio). Atualmente, já existe agravante no caso de crime cometido contra vítima menor de 14 anos, maior de 60 anos ou com deficiência; durante a gestação ou nos três meses posteriores ao parto; e na presença de descendente ou de ascendente da vítima, sem especificar que essa presença pode ser virtual ou física.

Centros de reabilitação

Para ajudar a diminuir os casos de violência contra a mulher, o Plenário aprovou o Projeto de Lei 5001/16, do Senado, que inclui entre as medidas protetivas da mulher vítima de agressão o comparecimento do agressor a programas de recuperação e reeducação. A matéria está em análise no Senado.

Segundo o texto, o juiz poderá determinar ainda o acompanhamento psicossocial do agressor por meio de atendimento individual e/ou em grupo de apoio.

Ressarcimento ao SUS

Agressores que praticarem violência doméstica e familiar poderão ser obrigados a ressarcir os custos dos serviços de saúde prestados pelo Sistema Único de Saúde (SUS) em situações relacionadas às vítimas desse tipo de violência. A medida consta do Projeto de Lei 9691/18, dos deputados Rafael Motta (PSB-RN) e Mariana Carvalho (PSDB-RO), aprovado pelo Plenário e enviado ao Senado.

De acordo com o texto, o agressor que, por ação ou omissão, causar lesão, violência física, sexual ou psicológica e dano moral ou patrimonial à mulher, será obrigado a ressarcir todos os danos causados, inclusive os custos do SUS envolvidos com os serviços de saúde prestados para o total tratamento das vítimas em situação de violência doméstica e familiar.

O dinheiro deverá ir para o fundo de saúde do ente federado responsável pelas unidades de saúde que prestarem os serviços.

Outras situações de ressarcimento, como as de uso do abrigo pelas vítimas de violência doméstica e dispositivos de monitoramento das vítimas de violência amparadas por medidas protetivas, também terão seus custos ressarcidos pelo agressor.

Informações sistematizadas

Também foi aprovada Política Nacional de Dados e Informações relacionadas à Violência contra as Mulheres (Pnainfo) foi criada pelo Projeto de Lei 5000/16, do Senado, aprovado pela Câmara neste ano. Devido às mudanças, a matéria será enviada ao Senado para nova votação.

A finalidade da política é reunir, organizar, sistematizar e disponibilizar dados e informações sobre todos os tipos de violência contra as mulheres.

Para os fins da Pnainfo, violência contra a mulher é definido como o ato ou a conduta praticados por razões relacionadas à condição de sexo feminino que causem morte, dano ou sofrimento físico, sexual ou psicológico à mulher, tanto na esfera pública como na esfera privada.

Os dados serão inseridos no Registro Unificado de Dados e Informações sobre a violência contra as mulheres, abrangendo registros administrativos referentes ao tema, serviços especializados 
de atendimento às mulheres em situação de violência e políticas públicas da área.

Esse cadastro permitirá a coleta de dados individualizados sobre as vítimas e o agressor, além da compilação da quantidade de mortes violentas de mulheres. ${ }^{70}$

70 PENA Maior para Crime de Feminicídio foi aprovada em 2018 pela Câmara. [s.n.: S.1.], 02 jan. 2019. Informação postada no site Câmara dos Deputados, no hiperlink Direitos Humanos. Disponível em: $<$ https://www.camara.leg.br/noticias/550226-pena-maior-para-crime-de-feminicidio-foi-aprovada-em-2018pela-camara/>. Acesso em: 15 out. 2019. 


\section{CONSIDERAÇÕES FINAIS}

A desigualdade entre homens e mulheres é incontroverso, principalmente por ainda ser cultivada a cultura de a mulher tem que ser boa esposa e boa mãe, qualquer comportamento fora disso não estaria condizente aos padrões idealizados para ela.

Todos os dias mulheres são violentadas e mortas por seus próprios familiares, os maiores índices da violência contra mulher no Brasil são da violência doméstica, a sociedade ainda cultiva uma cultura machista de que a mulher não pode ter voz ou vontade, de que é uma pessoa destinada a cumprir os desejos de sua família sem questionar.

Conforme explicado neste trabalho, a situação de desigualdade e violência de gênero propriamente dita coloca a mulher em posição de inferioridade desde sua existência e, mesmo com todo o avanço existente nos dispositivos legais para positivação de seus direitos e a proteção de sua integridade, as notícias diárias mostram que a lei apesar de "bela" na teoria, carece de eficácia na prática.

A sociedade ainda culpa a mulher pelo mal que lhe sobrevém, não raros são os relatos de vítimas que ao denunciar uma agressão escutaram coisas como: qual roupa você estava usando? Onde você estava? Em briga de marido e mulher não pode se meter? E por conta dessa cultura de culpabilização muitas deixam de denunciar e sofrem caladas, muitas acabam mortas mesmo quando já denunciaram inúmeras vezes.

Infelizmente, como um sujeito de direitos a mulher ainda é extremamente relativizada, após a promulgação da Lei Maria da Penha se pode constatar que falta efetividade nos mecanismos de coibição, prevenção e punição quanto a violência contra mulher. Em 2015 com o advento da Lei do Feminicídio que instituiu a morte de mulheres como qualificadora objetiva do crime de homicídio, constata-se um aumento bem significativo nos números de mulheres mortas vitimadas pela violência. 
O que se pode compreender é que necessita-se de uma mudança de conceitos e forma de tratamento, apesar da lei disciplinar que todos são iguais sem distinção de raça, cor, sexo, religião e outros fatores, a mulher continua sendo tratada em posição de desigualdade, violando previsão de direito fundamental pela Constituição Federal em seu artigo 5‥

Debates e clamores em torno da violência desenfreada têm alcançado somente, medidas na teoria, na prática a visão embaçada por uma cultura machista e patriarcal não tem permitido que as mulheres realmente se sintam seguras a viver em sociedade, se sintam respeitadas em suas vontades e direitos.

Conforme se pode entender, a violência de gênero é classe que abrange todas as outras espécies de violência contra mulher, uma vez que a conduta violência se dá em decorrência principalmente e precipuamente por conta de ela pertencer ao gênero feminino, a violência domestica e as demais formas são espécies dessa classificação.

O feminicídio guarda relação direta com a violência de gênero, uma vez que o gênero biológico serviu para qualificar o crime de tirar a vida de uma pessoa, no caso, por conta de ela ser mulher.

Assim sendo, na tentativa de minimizar a violência contra as mulheres, a Lei do Feminicídio entrou em vigência em março de 2015, como uma qualificadora penal e que reconhece o homicídio de mulheres como crime hediondo, este resultando de violência doméstica e familiar ou em razão de menosprezo ou discriminação da condição de mulher.

Em face da luta por justiça de gênero, a criminalização do feminicídio, para além de um caráter simbólico das normas jurídicas, é importante como um dos meios para garantir a efetivação da igualdade entre as pessoas e da dignidade humana. Assim, a especialização da legislação implica na luta pela erradicação da violência e na inserção do feminicídio como uma política de Estado, pois a morte de mulheres, decorrente da discriminação e violência de gênero, ultraja a consolidação dos direitos humanos. 


\section{REFERENCIAL BIBLIOGRÁFICO}

ACAYABA, Cinthia. Informação postada no site Globo G1, em 29 de abril de 2019. Disponível em: <https://g1.globo.com/sp/sao-paulo/noticia/2019/04/29/casos-defeminicidio-aumentam-76percent-no-10-trimestre-de-2019-em-sp-numero-demulheres-vitimas-de-homicidio-cai.ghtml>. Acesso em: 15 out. 2019.

ANDRADE, Vera Regina Pereira de. Pelas Mãos da Criminologia: O controle penal para além da (des)ilusão.

BRASIL. (Constituição 1988). Constituição da República Federativa do Brasil de 1988. Disponível em:

<http://www.planalto.gov.br/ccivil_03/constituicao/ConstituicaoCompilado.htm>. Acesso em: 15 out. 2019.

BRASIL. Decreto-Lei n. 2.848, de 7 de dezembro de 1940. Código Penal. Disponível em: <http://www.planalto.gov.br/ccivil_03/decretolei/Del2848compilado.htm>. Acesso em: 10 set. 2019.

BRASIL. Lei n. 13.104, de 9 de março de 2015. Altera o art. 121 do Decreto-Lei no 2.848, de 7 de dezembro de 1940 - Código Penal, para prever o feminicídio como circunstância qualificadora do crime de homicídio, e o art. 10 da Lei no 8.072, de 25 de julho de 1990, para incluir o feminicídio no rol dos crimes hediondos. Disponível em: <http://www.planalto.gov.br/ccivil_03/_Ato2015-

2018/2015/Lei/L13104.htm\#art1 >. Acesso em: 10 out. 2019.

BRASIL. Câmara dos Deputados. Câmara aprova aumento de pena para feminicídio. Informação postada no site Câmara.leg, em 28 de novembro de 2018. Disponível em: <https://www.camara.leg.br/noticias/548778-camara-aprovaaumento-de-pena-para-feminicidio/>. Acesso em: 20 out. 2019.

BRASIL. Conselho Nacional de Justiça. Formas de violência contra a mulher. Informação postada no hiperlink Programas e ações: Lei Maria da Penha, no site do CNJ. Disponível em: <https://www.cnj.jus.br/programas-e-acoes/lei-maria-dapenha/formas-de-violencia>. Acesso em: 01 set. 2019.

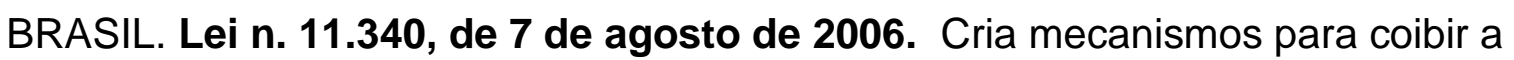
violência doméstica e familiar contra a mulher, nos termos do § 80 do art. 226 da Constituição Federal, da Convenção sobre a Eliminação de Todas as Formas de Discriminação contra as Mulheres e da Convenção Interamericana para Prevenir, Punir e Erradicar a Violência contra a Mulher; dispõe sobre a criação dos Juizados de Violência Doméstica e Familiar contra a Mulher; altera o Código de Processo Penal, o Código Penal e a Lei de Execução Penal; e dá outras providências. Disponível em: <http://www.planalto.gov.br/ccivil_03/_ato20042006/2006/lei/l11340.htm>. Acesso em: 15 out. $\overline{2019 .}$

BRASIL. Conselho Nacional de Justiça. Lei Maria da Penha. Informação postada no site CNJ. Disponível em: <https://www.cnj.jus.br/lei-maria-da-penha/>. Acesso em: 15 out. 2019. 
BEZERRA, Juliana. Lei Maria da Penha. Informação postada no site Toda Matéria. Disponível em: <https://www.todamateria.com.br/lei-maria-da-penha/>. Acesso em: 15 out. 2019

CALAZANS, Myllena. O processo de criação, aprovação e implementação da Lei Maria da Penha in CAMPOS, Carmen Hein de (org.) Lei Maria da Penha comentada em uma perspectiva jurídico-feminista. Rio de Janeiro: Lumen Juris, 2011.

CUNHA, Carolina. Feminicídio - Brasil é o 5ำ país em morte violentas de mulheres no mundo. Informação postada no site Vestibular Uol. Disponível em:

$<$ https://vestibular.uol.com.br/resumo-das-disciplinas/atualidades/feminicidio-brasil-eo-5-pais-em-morte-violentas-de-mulheres-no-mundo.htm?>. Acesso em: 25 out. 2019.

CUNHA, Carolina. Direitos femininos: uma luta por igualdade e direitos civis. Informação postada no site UOL. Disponível em:

$<$ http://vestibular.uol.com.br/resumo-das-disciplinas/atualidades/direitos-femininosuma-luta-por-igualdade-e-direitos-civis.htm>. Acesso em: 15 out. 2019.

CABELEIREIRA é morta pelo ex-marido com sete tiros dentro de salão de beleza em Minas Gerais. Informação postada no site O GLOBO, no hiperlink Brasil, em 21 jan. 2010, Minas Gerais. Disponível em: <http://oglobo.globo.com/brasil/cabeleireiramorta-pelo-ex-marido-com-sete-tiros-dentro-de-salao-de-beleza-em-minas-gerais$3065361>$. Acesso em: 20 out. 2019.

CAMPOS, Amini Haddad e CORRÊA, Lindinalva Rodrigues. Direitos humanos das mulheres. Curitiba: Juruá, 2007.

COULANGES, Fustel. Cidade Antiga. Tradução por Frederico Ozanam Pessoa de Barros. São Paulo: EDAMERIS, 1961.

CONEGERO, Daniel. O Que Significa a Lei do Levirato?. Informação postada no site Estilo adoração. Disponível em: <https://estiloadoracao.com/lei-do-levirato/>. Acesso em: 25 set. 2019.

DIAS, Maria Berenice. A Lei Maria da Penha na justiça: a efetividade da Lei 11.340/2006 de combate a violência doméstica e familiar contra a mulher. São Paulo: Revista dos Tribunais, 2007.

GARCEL, Fernando. Vizinhos chamaram polícia oito vezes antes de mulher ser morta por marido no PR. Informação postada no site Paraná Portal UOL, no hiperlink cidades, em 15 mar. 2019, Curitiba - PR. Disponível em: $<$ https://paranaportal.uol.com.br/cidades/vizinhos-chamaram-policia-oito-vezesantes-de-mulher-ser-morta-por-marido-no-pr/>. Acesso em: 25 out. 2019.

HIGA, Flávio da Costa. Assédio sexual no trabalho e discriminação de gênero: duas faces da mesma moeda? Revista de Direito FGV. v. 12 n. 2. MAI-AGO 2016. ISSN 2317-6172

INSTITUTO PATRÍCIA GALVÃO. Violência sexual. Disponível em: $<$ https://dossies.agenciapatriciagalvao.org.br/violencia/violencias/violencia-sexual/>. Acesso em: 10 set. 2019. 
IRMÃS indianas condenadas a estupro coletivo temem vingança, caso voltem à aldeia. Informação postada no site O GLOBO. Disponível:

<http://oglobo.globo.com/sociedade/irmas-indianas-condenadas-estupro-coletivotemem-vinganca-caso-voltem-aldeia-17378003 >. Acesso em: 02 set. 2019.

JESUS, Damásio de. Violência contra a mulher: aspectos criminais da Lei n. 11.540/2006. São Paulo: Saraiva, 2010.

LEGISLAÇÃO Sobre Violência Contra as Mulheres no Brasil. [S.n.t]. Informação postada no site Compromisso e Atitude Lei Maria da Penha. Disponível em: $<$ http://www.compromissoeatitude.org.br/legislacao-sobre-violencia-contra-asmulheres-no-brasil/>. Acesso em: 03 nov. 2019.

LENZI, Tié. O que é o movimento feminista? Informação postada no site Toda política. Disponível em: <https://www.todapolitica.com/movimento-feminista/>. Acesso em: 15 set. 2019.

MANZINI, Luana. Violência psicológica contra mulheres: uma abordagem com os instrumentos previstos na Lei Maria da Penha. Disponível em:

$<$ https://jus.com.br/artigos/64779/violencia-psicologica-contra-mulheres-umaabordagem-com-os-instrumentos-previstos-na-lei-maria-da-penha/1>. Acesso em: 10 set. 2019.

MALTA, Cynthia Guimarães Tostes. Evolução dos direitos da Mulher. Informação postada no site Geocites. Disponível em:

<http://www.geocities.ws/cynthiamalta/dirmul.html>. Acesso em: 15 out. 2019.

NUCCl, Guilherme de Souza. Código penal comentado. 17. ed. rev., atual. e ampl. Rio de Janeiro: Forense, 2017.

$\mathrm{NUCCl}$, Guilherme de Souza. Leis penais e processuais penais comentadas. 5. ed. São Paulo: Revista dos Tribunais, 2010.

PERES, Sarah. Vítima de feminicídio carregava medidas protetivas no bolso quando morreu. Informação postada no site Correio Braziliense, em 07 de maio de 2019. Disponível em:

<https://www.correiobraziliense.com.br/app/noticia/cidades/2019/05/07/interna_cidad esdf,753613/vitima-de-feminicidio-carregava-medidas-protetivas-bolso-quandomorreu.shtml>. Acesso em: 25 out. 2019.

PEREIRA, Rogério da Cunha. O que é violência patrimonial contra a mulher? Disponível em: <http://www.rodrigodacunha.adv.br/o-que-e-violencia-patrimonialcontra-mulher/>. Acesso em: 15 set. 2019.

PERROT, Michelle Minha história das mulheres. Tradução Angela M. S. Côrrea. São Paulo: Contexto, 2007.

PORFÍRIO, Francisco. Feminicídio. Informação postada no site Brasil Escola. Disponível em: <https://brasilescola.uol.com.br/sociologia/feminicidio.htm>. Acesso em: 15 out. 2019.

RIZZARDO, Arnaldo. Direitos de Família. 10. ed. Rio de Janeiro: Forense, 2019. 
SANTOS, Cecília MacDowell. Violência contra as Mulheres e Violência de Gênero: Notas sobre Estudos Feministas no Brasil. Informação postada no site Núcleo de Estudos da Violência da USP. Disponível:

<http://www.nevusp.org/downloads/down083.pdf>. Acesso em: 01 set. 2019.

SANTOS, Tales. As mulheres na história. Informação postada no site Mundo

Educação. Disponível em: <https://mundoeducacao.bol.uol.com.br/historiageral/asmulheres-na-historia.htm>. Acesso em: 25 set. 2019.

SÚMULA 588 do STJ Anotada (Violência Doméstica). [s.n.: S. I.], 15 abr. 2019. Informação postada no site Canal Ciências Criminais. Disponível em: <https://canalcienciascriminais.com.br/sumula-588-do-stj-anotada/>. Acesso em: 03 nov. 2019. 